\title{
Fault architecture and deformation processes within poorly lithified rift sediments, Central Greece
}

\author{
Sian Loveless*, Victor Bense, Jenni Turner \\ School of Environmental Sciences, Faculty of Science, University of East Anglia, Norwich Research Park, Norwich NR4 7TJ, UK
}

\section{A R T I C L E I N F O}

\section{Article history:}

Received 10 January 2011

Received in revised form

26 August 2011

Accepted 11 September 2011

Available online 22 September 2011

\section{Keywords:}

Mixed zone

Fault architecture

Poorly lithified sediment

Particulate flow

Cataclasis

Grain rotation

\begin{abstract}
A B S T R A C T
Deformation mechanisms and resultant fault architecture are primary controls on the permeability of faults in poorly lithified sediments. We characterise fault architecture using outcrop studies, hand samples, thin sections and grain-size data from a minor (1-10 m displacement) normal-fault array exposed within Gulf of Corinth rift sediments, Central Greece. These faults are dominated by mixed zones with poorly developed fault cores and damage zones. In poorly lithified sediment deformation is distributed across the mixed zone as beds are entrained and smeared. We find particulate flow aided by limited distributed cataclasis to be the primary deformation mechanism. Deformation may be localised in more competent sediments. Stratigraphic variations in sediment competency, and the subsequent alternating distributed and localised strain causes complexities within the mixed zone such as undeformed blocks or lenses of cohesive sediment, or asperities at the mixed zone/protolith boundary. Fault tip bifurcation and asperity removal are important processes in the evolution of these fault zones. Our results indicate that fault zone architecture and thus permeability is controlled by a range of factors including lithology, stratigraphy, cementation history and fault evolution, and that minor faults in poorly lithified sediment may significantly impact subsurface fluid flow.
\end{abstract}

(c) 2011 Elsevier Ltd. All rights reserved.

\section{Introduction}

Faults have been found to impact subsurface fluid migration patterns through the juxtaposition of rocks with contrasting hydraulic properties across the fault (e.g. Haneberg, 1995; Mailloux et al., 1999) and by introducing permeability heterogeneities and anisotropies within rocks (Bredehoeft et al., 1992; Caine et al., 1996) and sediments (Bense and Van Balen, 2004). As a result, faults can influence the accessibility of groundwater supplies (Bense et al., 2003; Minor and Hudson, 2006; Caine and Minor, 2009) and/or provide pathways between aquifers for contaminants such as brines (Stamatis and Voudouris, 2003; Bense and Person, 2006), and complicate environmental challenges such as the safe burial of radioactive waste (Bredehoeft, 1997). Hydrocarbon extraction (Antonellini and Aydin, 1994, 1995; Shipton et al., 2002; Fossen et al., 2007) and the security of sequestered carbon (Chadwick et al., 2009) may also be affected by the presence of faults. The potentially high impact of fault zones on the quality, security, and accessibility of subsurface resources requires an improved understanding of how faults affect the permeability of such reservoirs.

\footnotetext{
* Corresponding author. Tel.: +44 (0) 1603591338

E-mail address: s.loveless@uea.ac.uk (S. Loveless).
}

Poorly lithified basin sediments may form significant aquifers (e.g. Minor and Hudson, 2006), often in geological settings with widespread faults (Grauch et al., 2001). A conduit-barrier model of fault hydraulic behaviour developed for consolidated rock by Caine et al. (1996) has limited application to poorly lithified sediment deformed at shallow depths $(<1 \mathrm{~km})$. This is due to the considerable architectural differences that these fault zones exhibit (e.g. Heynekamp et al., 1999; Caine and Minor, 2009) as a result of contrasting rheological properties and confining pressures (Balsamo et al., 2008) (compare Fig. 1a and b). Outcrop based studies of faults in poorly lithified sediment generally predict that faults behave as hydraulic barriers, preventing cross-fault fluid flow and potentially compartmentalising regional aquifers, but many also suggest that fault zones may simultaneously behave as conduits, allowing along-fault fluid flow (Rawling et al., 2001; Bense et al., 2003; Caine and Minor, 2009). Examination of flow tracers, contemporary hydrological data, and numerical modelling of groundwater flow show evidence to support this latter model (Bredehoeft et al., 1992; Person et al., 2000; Heffner and Fairley, 2006; Bense and Person, 2006; Bense et al., 2008).

Despite the potential effects of faults in poorly lithified sediment at shallow depth on fluid flow (Sigda et al., 1999; Rawling et al., 2001; Minor and Hudson, 2006; Bense et al., 2008; Caine and Minor, 2009), studies specifically addressing their impacts remain 

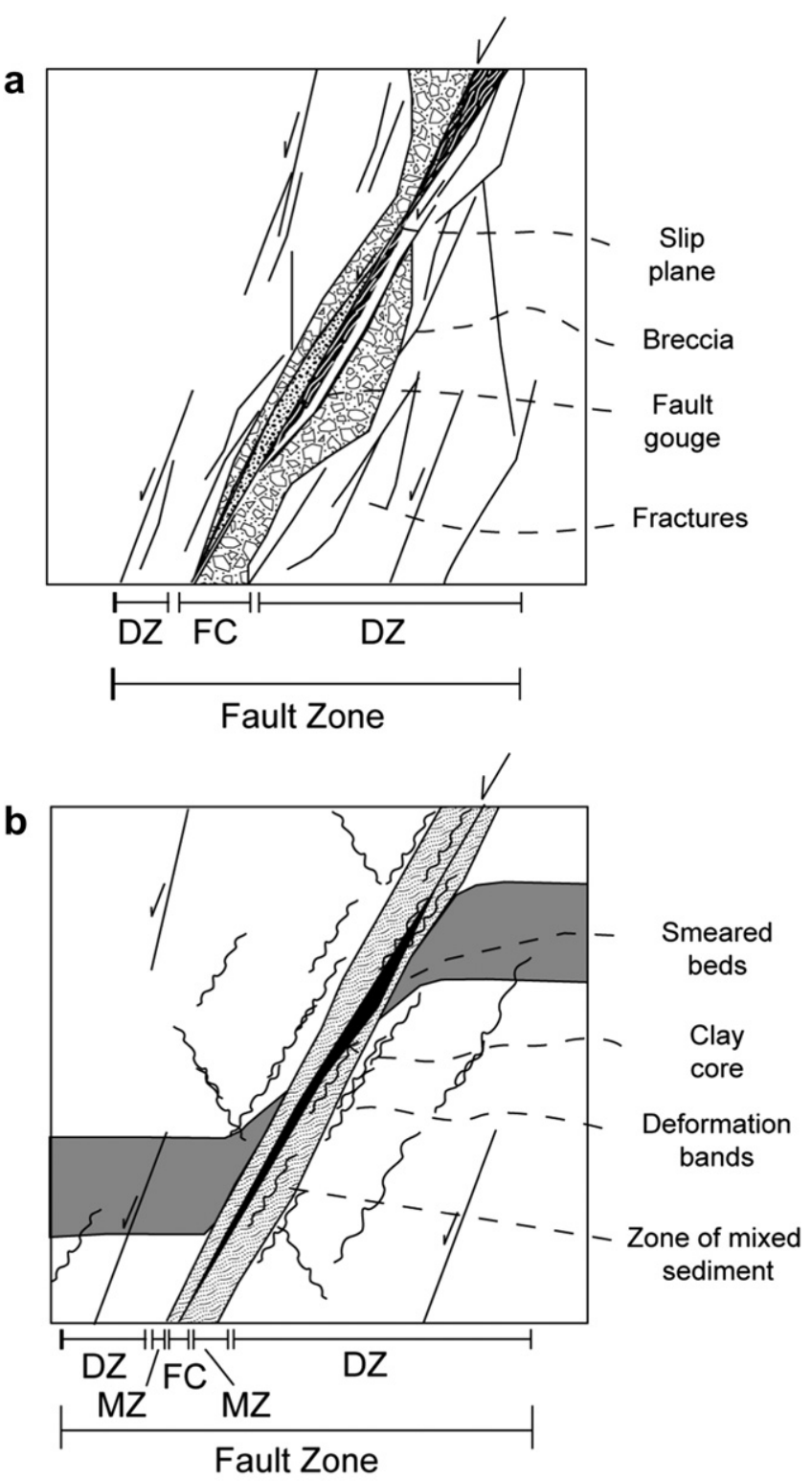

Not to Scale

Fig. 1. Typical architectural and structural elements of fault zones. a) Fault zone in crystalline rocks (e.g. Caine et al., 1996) with a fault core (FC) and damage zone (DZ). b) Fault zone in poorly lithified sediment (e.g. Heynekamp et al., 1999; Rawling and Goodwin, 2003; Rawling and Goodwin, 2006), the mixed zone (MZ) is a third architectural element.

sparse in relation to those in consolidated rock. In addition, the majority of previous outcrop studies of fault zones in poorly lithified sediment are from sand-dominated, continental sediments (Heynekamp et al., 1999; Sigda et al., 1999; Rawling et al., 2001; Bense et al., 2003; Minor and Hudson, 2006; Caine and Minor, 2009). As such, there may remain a greater variation of fault hydraulic architectures in poorly lithified sediment than previously reported (e.g. Heffner and Fairley, 2006) in different types of sediment. This premise is supported by the emerging recognition of a wider range of fault zone architecture and deformation mechanisms documented in recent studies (Balsamo and Storti, 2010, 2011) and to which this study contributes new insights.

A fault zone is the complete volume of rock deformed when lithospheric stresses cause two tectonic blocks to move in relation to one another. It is commonly comprised of two architectural elements; a fault core and damage zone (Fig. 1). The fault core is composed of structural elements that have accommodated the majority of fault displacement (e.g. Sibson, 1977; Caine et al., 1996). In poorly lithified, fine-grained sediment this is often reported as a low permeability, continuous clay smear (Heynekamp et al., 1999; Rawling et al., 2001; Bense et al., 2003; Caine and Minor, 2009) or a deformation band shear zone (Heynekamp et al., 1999; Rawling and Goodwin, 2003, 2006; Minor and Hudson, 2006) (Fig. 1b). Deformation bands are tabular zones of grain deformation, a few millimetres in width, and up to tens of meters in length. Each band accommodates up to a few centimetres of slip, and may occur separately or in clusters (Aydin, 1978; Antonellini and Aydin, 1994, 1995). Shear deformation bands, in which grains are compacted and/or fractured (cataclasis) have been found to reduce sediment porosity (Antonellini and Aydin, 1994; Rawling et al., 2001; Sternlof et al., 2006) and are commonly formed at depths greater than $1.5 \mathrm{~km}$ (Fossen et al., 2007). However, they have also been found within poorly lithified sediment that has not been buried to more than $1 \mathrm{~km}$ (Cashman and Cashman, 2000; Rawling and Goodwin, 2003, 2006; Caine and Minor, 2009; Balsamo and Storti, 2010).

The damage zone flanks the fault core. Structural elements within this zone are mechanically related to the growth of the fault and may comprise subsidiary faults or fracture networks that may increase permeability (e.g. Sibson, 1977; Caine et al., 1996) (Fig. 1a). In fault zones within poorly lithified sands shear deformation bands commonly replace fracture networks as the basic structural element within the damage zone (Heynekamp et al., 1999; Bense et al., 2003; Rawling et al., 2001; Rawling and Goodwin, 2003, 2006; Minor and Hudson, 2006) (Fig. 1b), leading to a reduced fault zone permeability (e.g. Rawling et al., 2001). At shallower depths in extensional settings disaggregation bands may occur in damage zones in which grains are neither crushed nor compacted but sediment structure is disaggregated, which may act to focus fluid flow (Du Bernard et al., 2002; Bense et al., 2003; Minor and Hudson, 2006; Balsamo et al., 2008). A damage zone is usually identified where the frequency of associated structural elements are above background levels and can be attributed to a particular fault (Childs et al., 2009).

In poorly lithified sediment a third architectural element, the mixed zone, separates the fault core and damage zone (e.g. Mozley and Goodwin, 1995; Heynekamp et al., 1999; Rawling and Goodwin, 2006) (Fig. 1b), referring to the mixed nature of these zones (Rawling and Goodwin, 2006). The mixed zone can consist of variably deformed, entrained and attenuated beds that are rotated parallel to the fault zone, forming smears along the fault trace (Bense and Person, 2006) with a continuous displacement geometry (e.g. Lindsay et al., 1993). Initial sedimentary bed characteristics are progressively modified with increasing displacement within the fault zone, and can eventually be lost entirely where fault displacement exceeds bed thickness, resulting in a largely homogenised zone of beds that are mixed at the grain scale (Mozley and Goodwin, 1995; Heynekamp et al., 1999; Rawling and Goodwin, 2006). Lenses or blocks of relatively undeformed sediment can also be found within mixed zones (Rawling and Goodwin, 2006; Caine and Minor, 2009). Localised shear zones, or deformation band shear zones commonly separate the mixed zone from the undeformed sediment (Rawling and Goodwin, 2006; Caine and Minor, 2009). Mixed zones may contribute to the low permeability of fault zones in poorly lithified sediments (Caine and Minor, 2009).

The structural elements present in a fault zone vary depending on the mechanism of deformation, i.e. the mechanical processes by which a rock or sediment responds to applied stress. Particulate flow is the dominant deformation mechanism within most faults in poorly lithified sediment (e.g. Rawling and Goodwin, 2003; Bense et al., 2003; Balsamo et al., 2008; Caine and Minor, 2009) in 
which grain-scale deformation occurs by grains sliding and rotating along their boundaries. If this deformation occurs without cataclasis then the particulate flow is known as independent particulate flow (Borradaile, 1981; Bense et al., 2003). In controlled particulate flow a limited amount of cataclasis enables sustained particulate flow (Borradaile, 1981; Rawling and Goodwin, 2003, 2006; Balsamo et al., 2008). In some fault zones in poorly lithified sediment cataclasis may even be the dominant deformation mechanism (Balsamo and Storti, 2010, 2011).

This work contributes to the growing body of literature addressing the nature of fault zones in poorly lithified sediment. We present results from an outcrop study in which we have examined an array of well exposed minor ( $<10 \mathrm{~m}$ displacement) normal faults cutting poorly lithified sediments dominated by coarse coastal deposits, within the Gulf of Corinth rift, in Central Greece in order to elucidate characteristic fault zone architectures and evolution.

\section{Geological setting}

The study area is located immediately north of Loutraki town, to the northeast of the Lechion Gulf, which is a sub-basin of the rapidly extending Gulf of Corinth rift, Central Greece (Fig. 2a and b). The minor normal-fault array is exposed in a road cutting on the outskirts of Loutraki. Three near-parallel sections, two either side of the road, the third tens of meters to the south (Fig. 2c), provide a quasi-3D view of the fault system. The minor-fault array is within the hangingwall to the major E-W trending Lower Loutraki normal fault, approximately $150 \mathrm{~m}$ to the south of the main fault scarp. The Lower Loutraki fault separates the relatively flat Loutraki plain on the hangingwall and the topographic high of the Gerania Range on the footwall to the north. Based upon local topography we estimate that the minimum dip-slip displacement across the Lower Loutraki fault is greater than $600 \mathrm{~m}$. A highly irregular and eroded Lower Loutraki fault scarp (Leeder et al., 2005) and limited displacement of Holocene fan breccia and colluvium (Turner et al., 2010), suggest a lack of Holocene activity along the Lower Loutraki fault.

Within the study area Pliocene to early Quaternary shallow basin sands and marls are unconformably overlain by a sequence of Quaternary deltaic sediments, typical of uplifted basin margin sediments along the coastline of the Lechaion Gulf (e.g. Collier, 1990; Dia et al., 1997; Roberts et al., 2009; Turner et al., 2010). The marls are either cohesive fine-grained (silt-clay) carbonates or less cohesive silty carbonates interbedded with sands. These sediments are cut by small-scale (displacement $<1 \mathrm{~m}$ ) conjugate faults, which are not discussed in this study. The deltaic sequence comprises alternating beds of coarse sand, bladed beach pebbles, alluvial gravel and cobbles and very poorly sorted talus. Bed thickness ranges from $0.1 \mathrm{~m}$ to $5 \mathrm{~m}$ with considerable lateral variability. Pebble and sand beds are typically composed of approximately 60\% limestone, $20 \%$ chert, $15 \%$ quartz and $5 \%$ serpentinite fragments and talus is composed predominantly of limestone clasts.

The normal-fault array we study here forms an asymmetric graben (Figs. 2c and 3) bounded by Faults 1 and 3, which probably formed in response to activity on the Lower Loutraki fault. These faults cut both the fine-grained and delta deposits. Faults 1 and 3 have displacements of around $7 \mathrm{~m}$, and the remaining faults record between 1 and $4 \mathrm{~m}$ of displacement. On the east side of the graben faults strike approximately NE and dip to the NW, and faults in the west side of the graben strike approximately NW, and dip approximately $\mathrm{NE}$; in planform these faults should converge towards the south of the outcrop (Fig. 2c). Slickenlines on localised shear surfaces plunge obliquely on normally separated fault surfaces, indicating an SE motion (plunge ranges from $40^{\circ} / 080$ to $50^{\circ} / 055$ ) on the NE dipping fault and an SW motion (plunge ranges from $25^{\circ} / 189$ to $48^{\circ} / 170$ ) on the NW dipping fault.
The Quaternary marine and beach sediments are now at an elevation of $80 \mathrm{~m}$ above present day sea level such that with a minimum estimated uplift rate of $0.22 \mathrm{~mm} \mathrm{yr}^{-1}$ (Turner et al., 2010) the maximum burial of these sediments is likely to be equivalent to the maximum thickness of the succession, $50 \mathrm{~m}$. Some beds are slightly lithified due to localised cementation by iron oxide or micritic calcite (Fig. 4). We interpret an irregularly shaped smear of fine sand within the mixed zone of Fault 3, and crevices within the hangingwall sand of Fault 2 which are filled with pebbles from the overlying bed (Fig. 3), as fluid escape structures indicative of liquefaction, possibly as a result of seismicity in the area, indicating that sediments were probably water-saturated at the time of deformation. This is further corroborated by the presence of extensive bed-parallel calcite cementation, which can be a feature of sediments in the intertidal zone (e.g. Rey et al., 2004).

\section{Methodology}

We mapped the fault zone architecture of eight faults in the Loutraki study area. Fault zone microstructures were examined in detail to establish the nature of deformation. Details of the applied methodologies are summarised below.

\subsection{Fault architecture characterisation}

The fault zone architecture; fault core, mixed zone and damage zone (Fig. 1b), were ascertained for each mapped fault. We have identified mixed zones as the regions of mixed nature within fault zones that are structurally analagous to those reported by Rawling and Goodwin (2006). Because these zones accommodate the majority of fault displacement they could also be termed fault cores yet we feel the hydrological importance of the absence of architectural elements commonly found in fault cores (such as clay core and deformation bands) would be misleading for these purposes. Minimum and maximum fault thickness was also measured for each fault from field measurements and scaled photographs. Average fault thickness was determined from the mean of ten equally spaced locations along the dip of the fault. Fault thickness was recorded as the distance across the fault zone that exhibited the majority of displacement; this was easily evident in all the faults and synonymous with the mixed zone thickness.

\subsection{Clast orientations}

Clast re-orientation is a widespread feature of fault zones in poorly lithified sediment (e.g. Goodwin and Tikoff, 2002). Apparent grain orientation was visually identified, and the outlines of bladed clasts were defined manually from photographs of Fault 1A (Fig. 3). Three dimensional pebble orientations were measured in the field at $0.1 \mathrm{~m}$ intervals along vertical and horizontal transects across the footwall and mixed zone of the same fault, to determine the extent of pebble re-orientation. Both the magnitude of dip and dip direction of the long axis of the pebbles were recorded, along with pebble dimensions. Results were filtered to include only the pebbles which could be termed bladed (cf. Perry and Taylor, 2007). The orientations of these pebbles were then plotted on equal area stereonets (Holcombe, 2010). Pebble dip direction was plotted against distance across the fault zone, to examine shifts in orientation trends.

\subsection{Hand samples and thin sections}

Hand samples were collected to examine fault zone microstructures such as clast rotation, cataclasis, and grain-scale mixing of sediment from different source beds. The poorly consolidated 
a

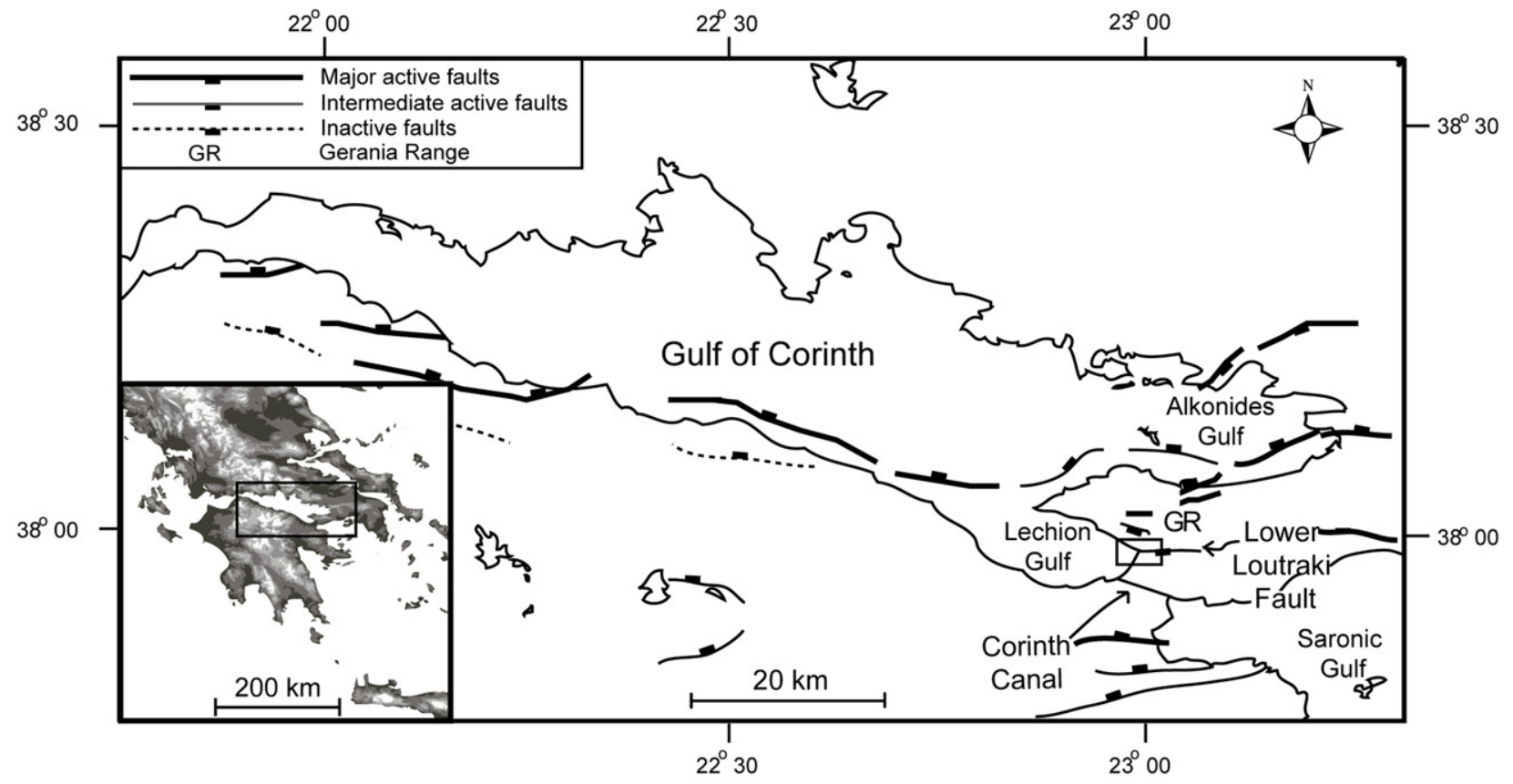

b
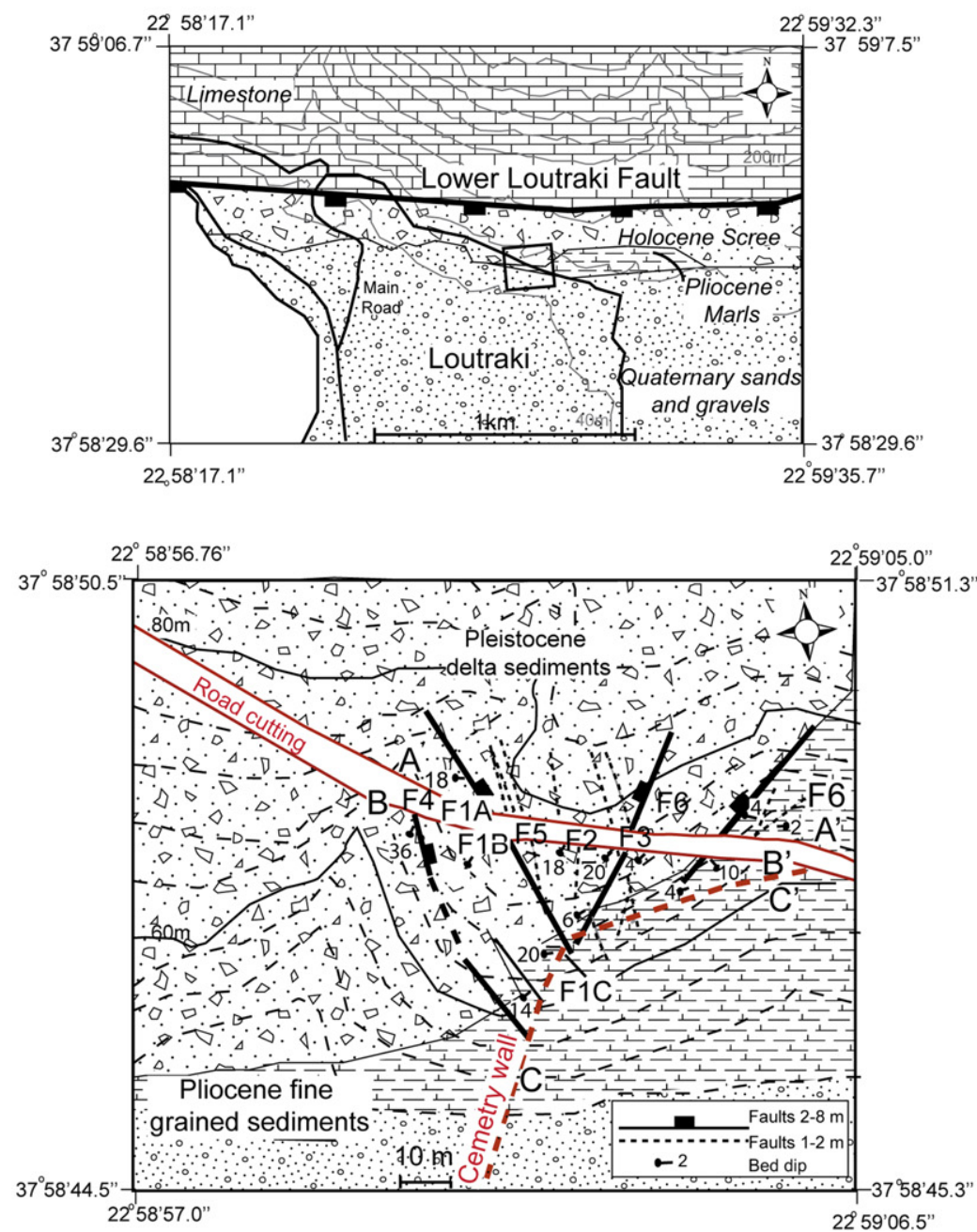

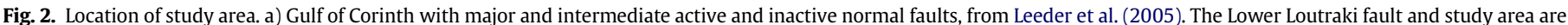

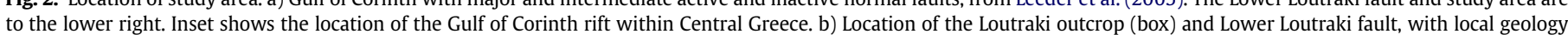

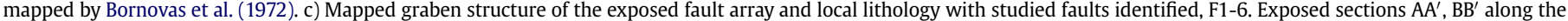
road, and $\mathrm{CC}^{\prime}$ along a cemetery wall are shown. 


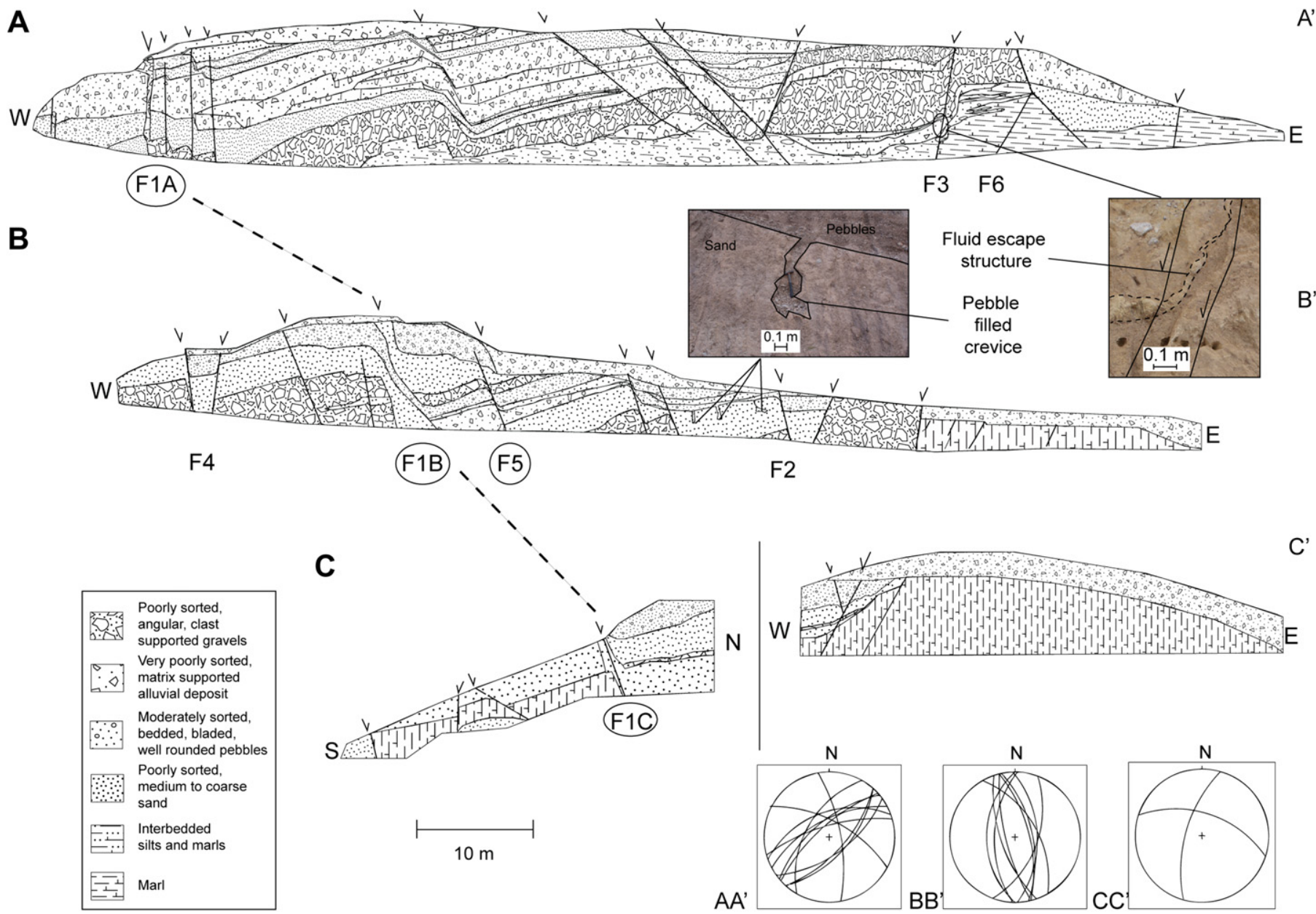

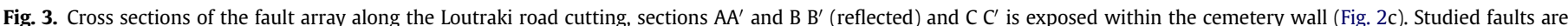

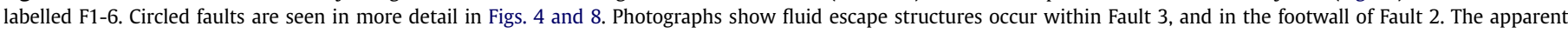
orientations of faults are shown in stereonets $\mathrm{AA}^{\prime}$ to $\mathrm{CC}^{\prime}$, corresponding to sections.

nature of the sediments meant that impregnation with a low viscosity resin was required. Approximately $25 \mathrm{ml}$ of resin mixed with a blue dye was poured into a divot excavated into the fault trace, and allowed to permeate. The hardened block of resin impregnated sediment was collected after $24 \mathrm{~h}$. Later, samples were fully impregnated in the laboratory using the same type of resin and then sliced, usually perpendicular to the fault strike and parallel to the direction of fault movement. Thin sections were prepared from areas of specific interest, and analysed using a petrographic microscope.

Two-dimensional grain shape was identified from thin sections of the mixed zone and footwall sediment from a hand sample from Fault 5. A grid with equally spaced horizontal and vertical transects was placed over the thin section images and lithology, degree of equancy, angularity and grain edge characteristics were recorded at the intersections. More than thirty grains were analysed in each zone to provide a statistically significant sample.

\subsection{Grain-size distributions}

Grain-size distributions, median, mode, mean, standard deviation and sorting parameters of grain-size samples from fault zones and hangingwall and footwall sediment were analysed, so as to identify changes to sediment characteristics that may be indicative of fault zone processes (e.g. Balsamo and Storti, 2011). The maximum possible sample sizes were collected from the field $(50-250 \mathrm{~g})$ to produce a representative sample. Clasts greater than $40 \mathrm{~mm}$ in diameter were measured in the field using callipers. The remainder of the sample was dry sieved in the laboratory to $1.4 \mathrm{~mm}$, and fractions weighed to an accuracy of $0.1 \mathrm{~g}$. Sediment with a grain diameter $<1.4 \mathrm{~mm}$ was suspended in $50 \mathrm{ml}$ of water and run through a Malvern Laser Particle Scanner (MLPS). Three runs minimised sample error and the average was used in the final results. For some samples it was necessary to add a small amount of Calgon (water softener) to the solution to break up cohesive grains. Field, sieve and MLPS results were then combined to produce a complete grain-size distribution for each sample.

\section{Results}

In this section we describe the fault zone structures and microstructures of two faults in the study area, one of which outcrops in three locations, which we consider to be structurally representative of those within the Loutraki section; Fault 1 A, B and C, and Fault 5 (Figs. 2 and 3).

\subsection{Fault $1 \mathrm{~A}$}

Section A exposes Fault 1 (displacement $\sim 7 \mathrm{~m}$ ) cutting a heterogeneous sequence of coarse sediment (Fig. 4a). All beds 
a

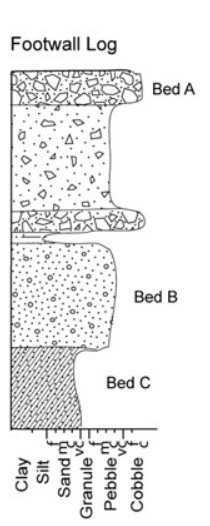

b

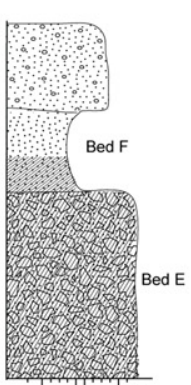

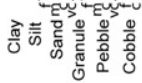

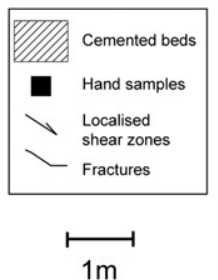

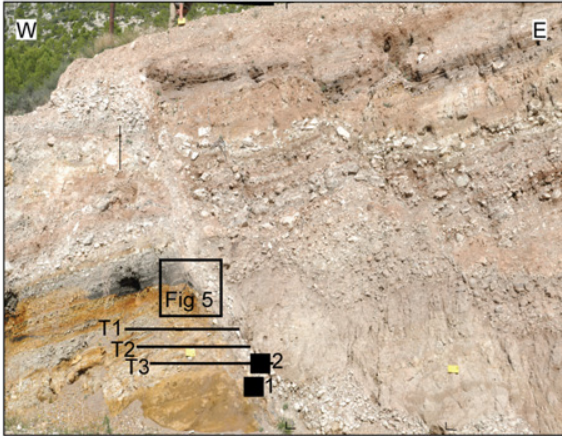

Fault $1 \mathrm{~A}$

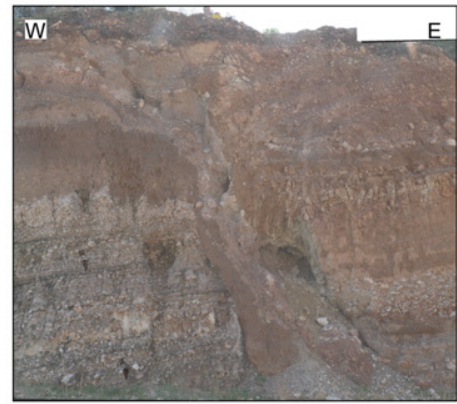

Fault 1B

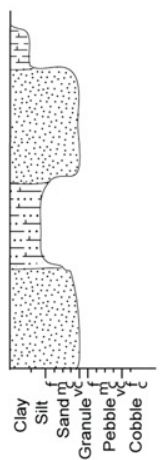

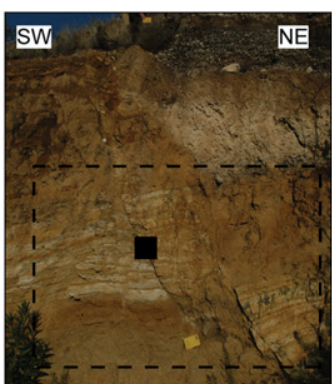

Fault 1C

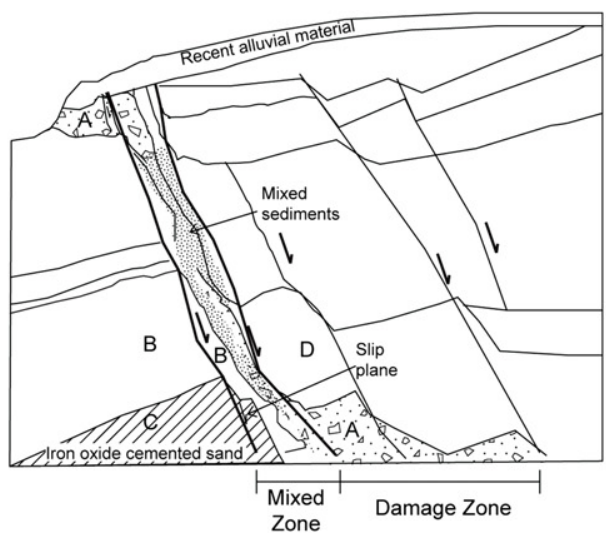

Hangingwall Log
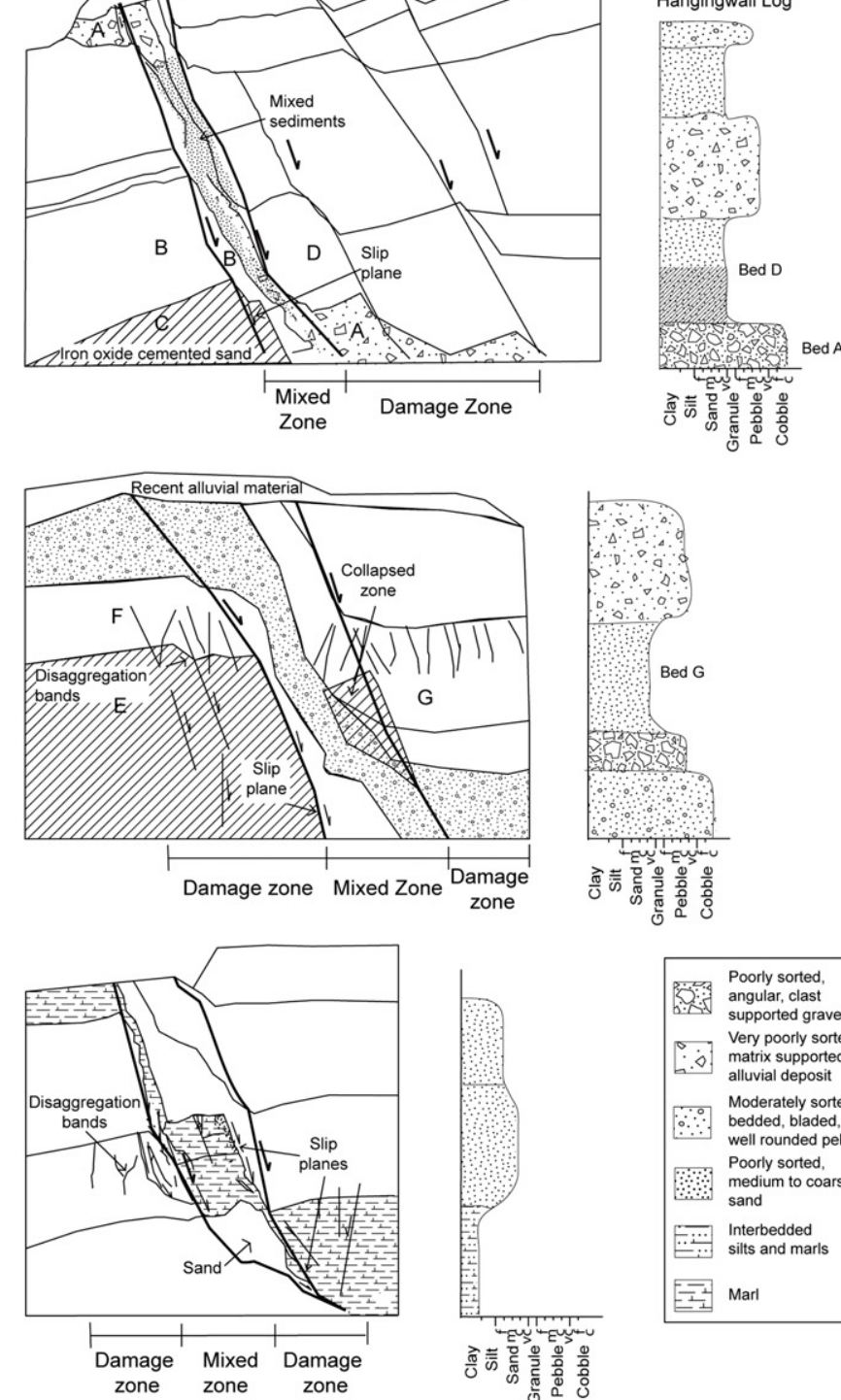
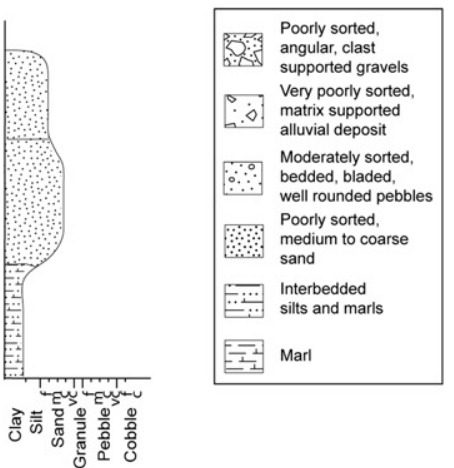

zone zone zone

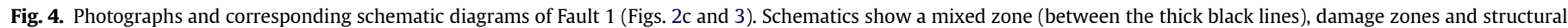

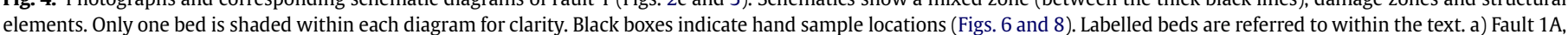

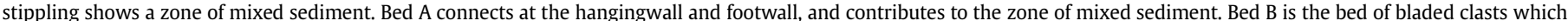

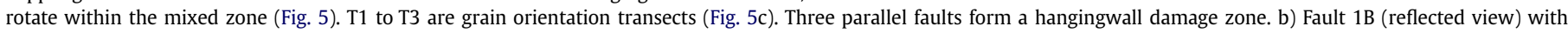

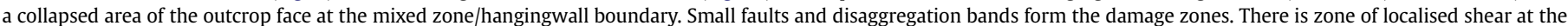

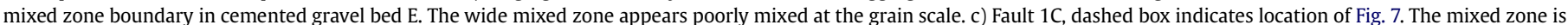

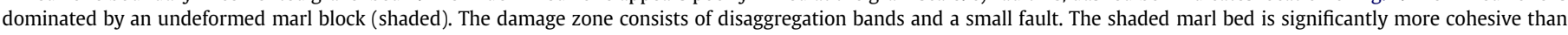
other sediment in the outcrop. Localised shear zones are common within the marl.

are very poorly lithified with the exception of sand bed $C$ in the footwall which is cemented by iron-oxide, and sand bed $D$ in the hangingwall, which is partially cemented with calcite. Beds cut by the fault are entrained and smeared within a mixed zone. These beds are rotated and dip 50 to $60^{\circ}$ within the mixed zone, becoming increasingly attenuated and less recognisable with distance from the source bed. Bed A (Fig. 4a), for example, is attached to the source bed in the footwall and hangingwall but appears to be mixed with surrounding beds through most of the mixed zone. Bed $C$ is bound by a zone of localised strain at the mixed zone boundary (Figs. 4a and 6a). In the hangingwall three fault-parallel secondary faults with up to $1 \mathrm{~m}$ displacement each, cut all lithologies (Fig. 4a).
Within the mixed zone of Fault $1 \mathrm{~A}$ pebbles from bed $\mathrm{B}$ are predominantly rotated consistent with fault displacement direction (Fig. 5a). However, in some zones pebbles remain oriented parallel to the original bed. Fig. 5b shows values of the orientation of the long axes of bladed pebbles from this bed in the footwall and mixed zone. Pebble axes within the undisturbed bed have a mean dip of $36^{\circ}$ to the SSW, reflecting dip of the sedimentary bedding. Dip changes to $37^{\circ}$ to the ESE within the mixed zone. There is also a slight increase in the spread of pebble orientations within the mixed zone compared with the footwall (Fig. 5b). Fig. 5c shows a plot of measured pebble dip directions from bed $\mathrm{B}$, from $1 \mathrm{~m}$ into the footwall through to the mixed zone/hangingwall boundary. Clast dip direction changes abruptly at the mixed zone boundary 
a
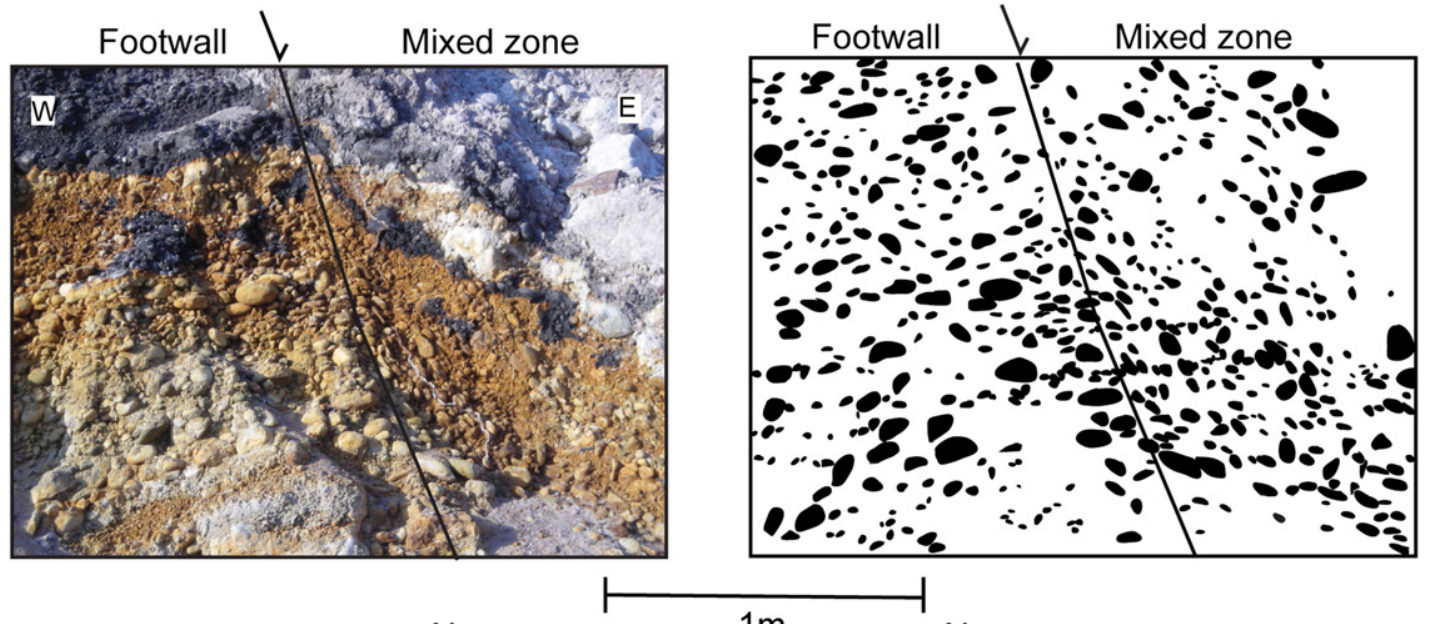

b

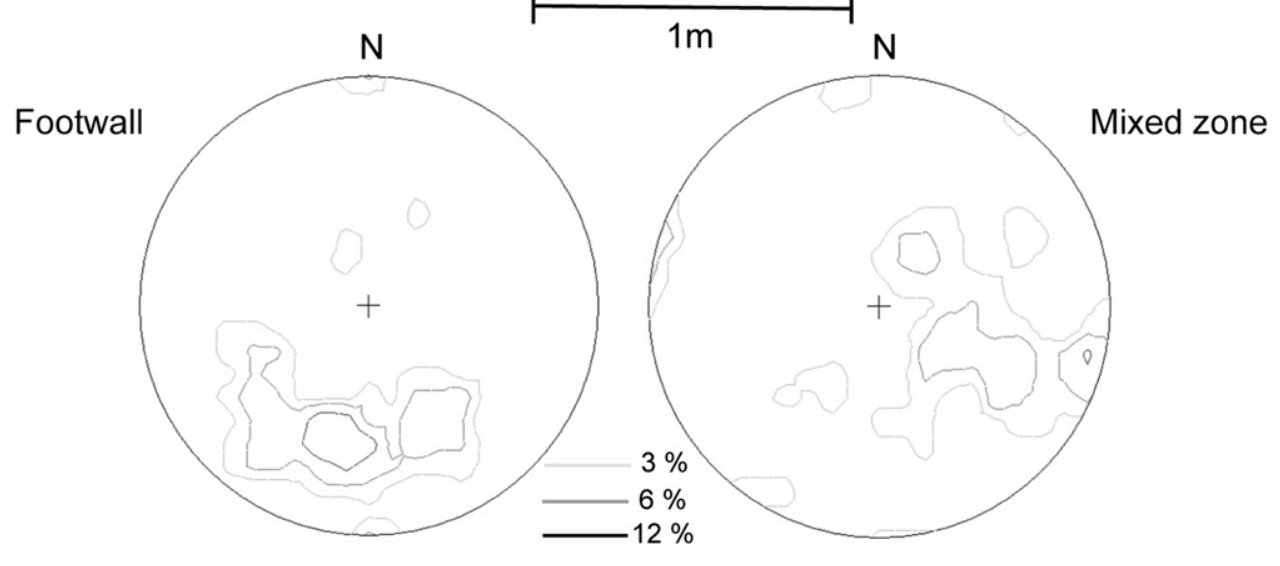

C

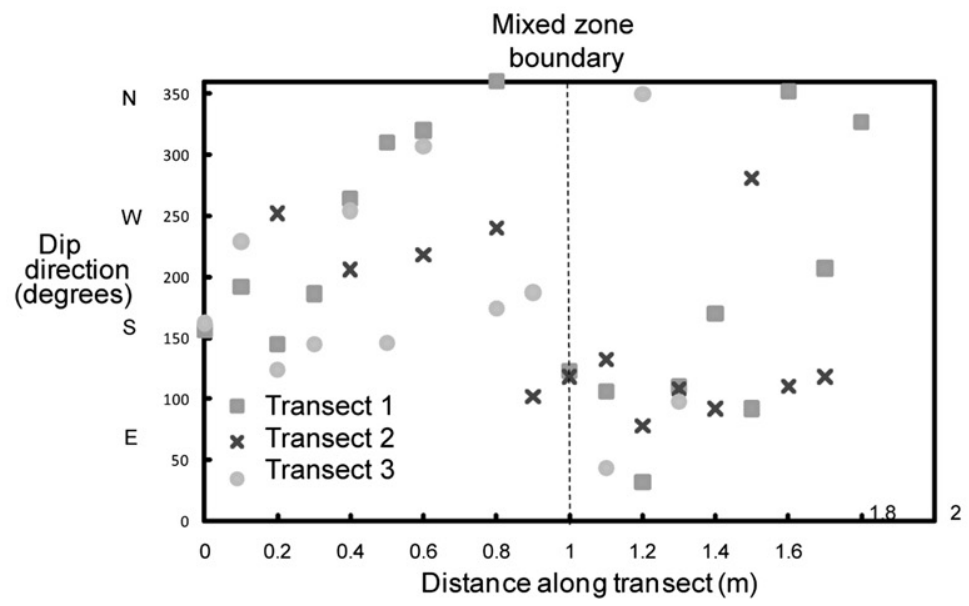

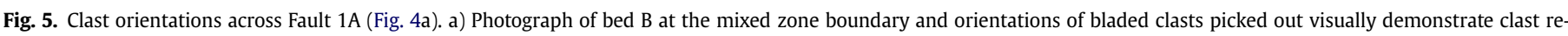

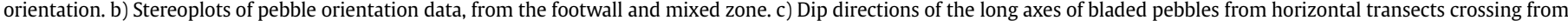
the footwall into the mixed zone (transect location indicated in Fig. 4a).

from SW to SE, followed by a subsequent spreading of dip orientations towards the centre of the mixed zone. Variations in independent dip values across the transects were negligible due to the high angle of sedimentary bedding in the footwall.

Five hand samples were taken from across the Fault $1 \mathrm{~A}$ mixed zone, examples are shown in Fig. 6 of the footwall/mixed zone boundary (a) and the centre of the mixed zone (b) (Fig. 4a). Both samples show larger clasts $(>5 \mathrm{~mm})$ commonly consistently aligned with the fault displacement direction. Smaller clasts $(<5 \mathrm{~mm})$ and zones of groundmass commonly dip coherently, although this may not be consistent with fault displacement direction. Grains appear to be less well orientated in Fig. 6b (centre of the mixed zone) than in Fig. 6a (mixed zone boundary). There is a greater proportion of pore space occupied by fine grains (Fig. 6e) and calcite cement (Fig. $6 \mathrm{c}$ ) in the hand sample from the centre of the mixed zone than the thin section from the mixed zone boundary, causing a decrease in porosity. Thin sections from the mixed zone show evidence for grains having fractured by a combination of spalling and flaking, and surface crushing (Fig. 6d and $\mathrm{f}$ ). 
a

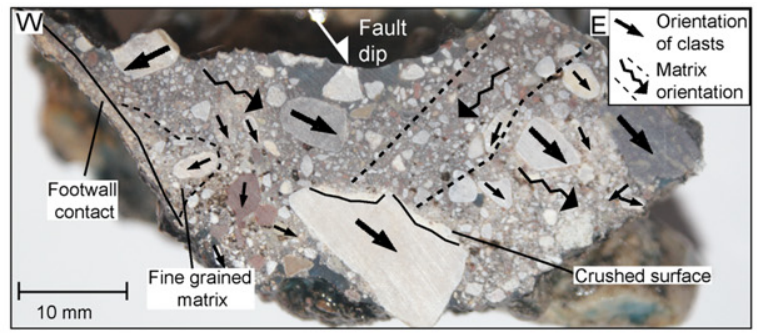

b

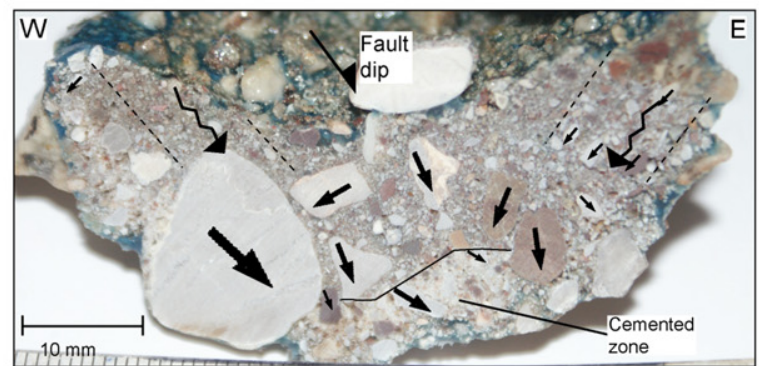

C
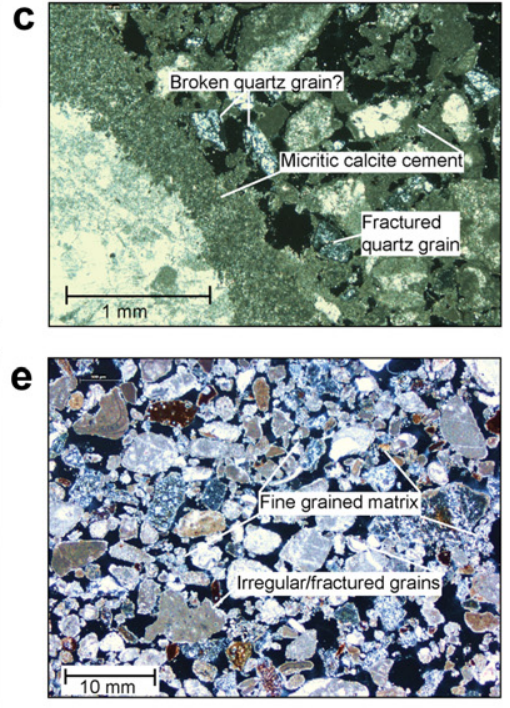
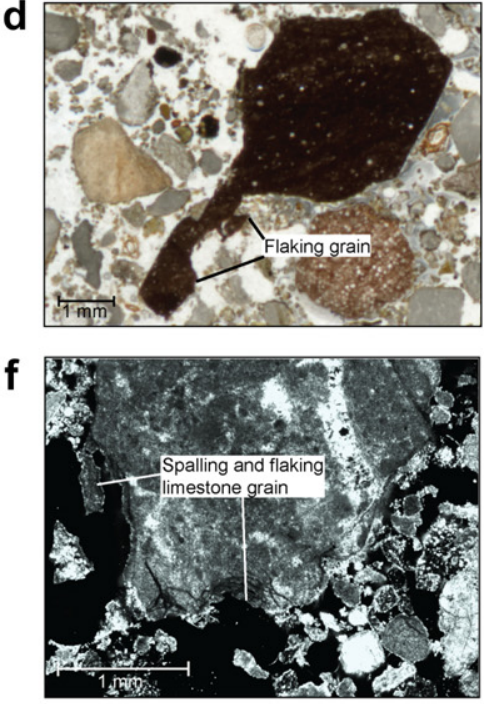

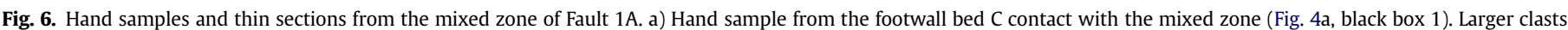

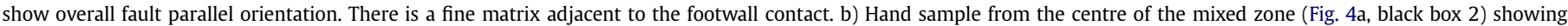

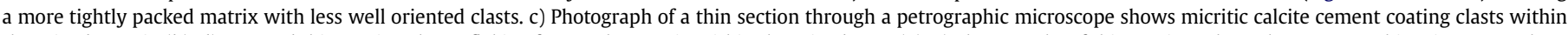

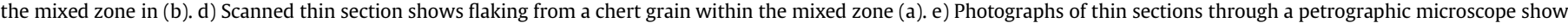
fine-grained matrix and irregular and fractured grains from the mixed zone and f) a flaking and spalling limestone grain from the mixed zone.

\subsection{Fault $1 B$}

Fault $1 \mathrm{~B}$ is exposed across the road from Fault $1 \mathrm{~A}$, and similarly cuts poorly lithified, coarse clastic sediments (Fig. 4b). There is one calcite cemented gravel bed (E) at the base of the footwall exposure that is separated from the mixed zone by a localised shear zone. Other beds cut by the fault are entrained and smeared within a single mixed zone. In contrast to beds in Fault $1 \mathrm{~A}$ the coarse sand bed $F$ (footwall), retains definition within the mixed zone throughout the exposure, despite a fault displacement approximately four times greater than the original bed thickness. The localised shear zone in the cemented gravel bed dips $68^{\circ} \mathrm{NE}$ compared to an average of $55^{\circ} \mathrm{NE}$ at poorly lithified sand bed contacts. The footwall cemented gravel bed has sustained a number of brittle fractures and a small fault parallel to the dip of the main fault (displacement $\sim 0.2 \mathrm{~m}$ ) within the damage zone and there are some possible disaggregation bands in sand beds $F$ and $G$ (Fig. 4b).

\subsection{Fault $1 C$}

Fault $1 \mathrm{C}$ is exposed down dip and along strike of Faults $1 \mathrm{~A}$ and $\mathrm{B}$ (Fig. 4c). In section $C$ sediment is characterised by an alternating sequence of poorly lithified sand, slightly cohesive bedded marls and silts, and fine-grained marl that was found to be noticeably more cohesive than other beds during sample collection, and has greater than $45 \%$ grain-size $<0.03 \mathrm{~mm}$ (Fig. 7b). Displacement within Fault $1 \mathrm{C}$ is again focussed within a mixed zone (Fig. 4c). Poorly lithified sands are entrained and smeared within the mixed zone in a similar fashion to that observed within Fault $1 \mathrm{~A}$ and $\mathrm{B}$, however a block of the cohesive marl bed (shaded bed in Figs. 4c and 7a) forms a major component of the mixed zone of Fault 1C. This block is largely internally undeformed except for occasional fractures, and is bound by near-vertical localised shear zones. A smear connects this to the source bed in the hangingwall and footwall (Fig. 4c). There are a number of smaller blocks of a similar nature towards the base of the outcrop (Fig. 4c). The mixed zone boundaries within silts and marls are invariably more discrete than within poorly lithified sands. Contacts within the cohesive marls are generally localised shear zones (Figs. 4c and 7c) with striations. Silt and marl beds exhibit conjugate disaggregation bands forming a minor damage zone, and a small antithetic fault originates in the marl bed at the base of the footwall exposure (Fig. 4c). Locally the marl has steeper contact orientations, $60^{\circ}\left( \pm 9^{\circ}\right)$, than sand bed contacts, $47^{\circ}\left( \pm 6^{\circ}\right)$ (Fig. $4 \mathrm{c}$ ).

Grain-size distributions from grain-size samples taken from across Fault $1 \mathrm{C}$ demonstrate distinguishing characteristics for each sediment type which are similar within the undeformed sediment and mixed zone. In Fig. $7 \mathrm{~b}$ these are separated into distinctive beds, the black line indicating the average grain-size distribution for each graph. The sand beds in the footwall, mixed zone and hangingwall have relatively broad modal peaks from $0.5 \mathrm{~mm}$ to $2 \mathrm{~mm}$ (up to $30 \%$ of the sample), and a smaller peak at $<0.03 \mathrm{~mm}$ ( $10 \%$ of the sample). The footwall silty-marl has a modal peak at $<0.03 \mathrm{~mm}$ ( $>20 \%$ of the sample) and a second broad peak from 0.1 to $1 \mathrm{~mm}$ (up to $20 \%$ of the sample). The cohesive marl in the hangingwall and the mixed zone has a modal peak at $<0.03$ ( $>45 \%$ of the sample) and a second peak at $0.2 \mathrm{~mm}$ ( $20 \%$ of the sample).

Standard deviation of the sampled mean grain-sizes is greater in the mixed zone for both $\operatorname{marl}(0.15 \mathrm{~mm})$ and sand $(0.92 \mathrm{~mm})$ than their undeformed source beds $(0.07 \mathrm{~mm}$ and $0.19 \mathrm{~mm}$ respectively) (Fig. 7b). Within the mixed zone sands there are a number of samples with grain-size distribution profiles that deviate from the average, as indicated by stars (Fig. 7a and b). The grain-size distributions of sand samples T1 7 (Fig. 7b v), T2 H (Fig. 7b vi) and T5 V (Fig. 7b viii) all have a higher percentage of fine grains and broader peaks at the modal grain-size. Sand samples T5 Q (Fig. 7b viii) and T3 $\mathrm{g}$ (Fig. 7b vii) have a higher percentage of fine grains relative to the average grain-size distributions. Samples T2 F and T2 G (Fig. 7b iv) have coarser modal peaks, which probably results from cemented grains that were not properly disaggregated during analysis. Within the mixed zone marl, sample T3 e (Fig. 7b ix) has a smaller modal peak at grain-sizes $<0.03 \mathrm{~mm}$ and a third, coarser peak at $0.7 \mathrm{~mm}$.

A hand sample was taken from sand smeared between a localised shear zone in marl at the footwall/mixed zone boundary and another that bounds the mixed zone marl block 

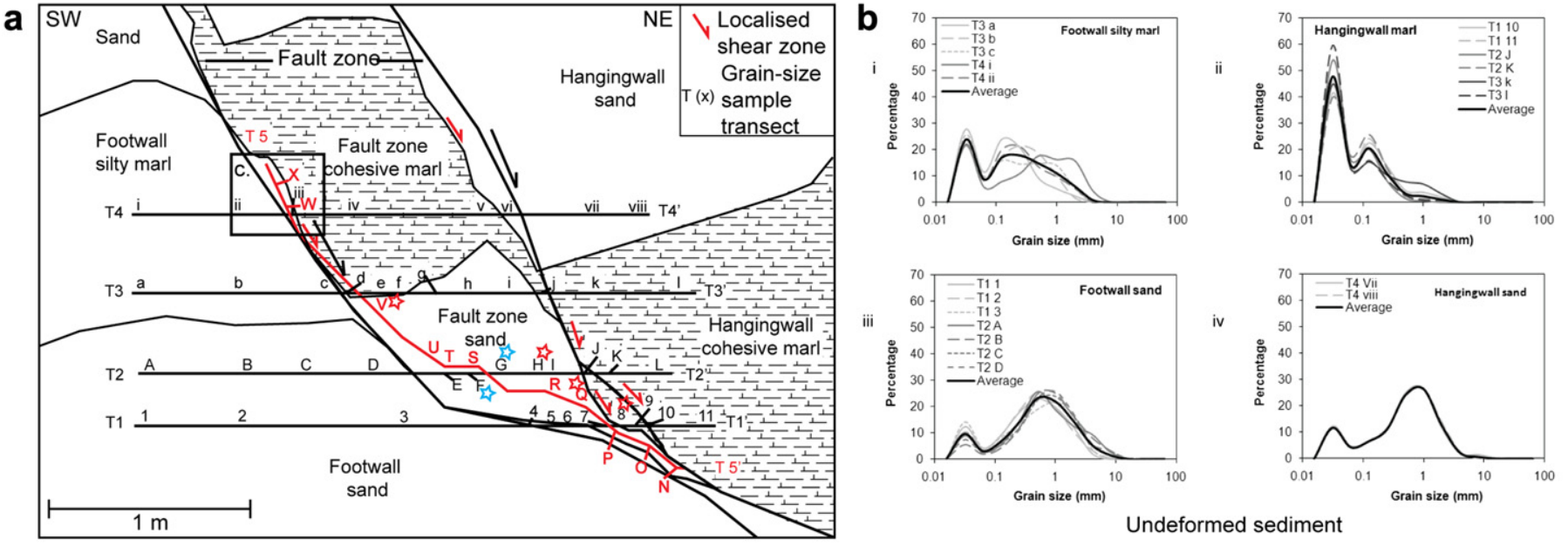

C

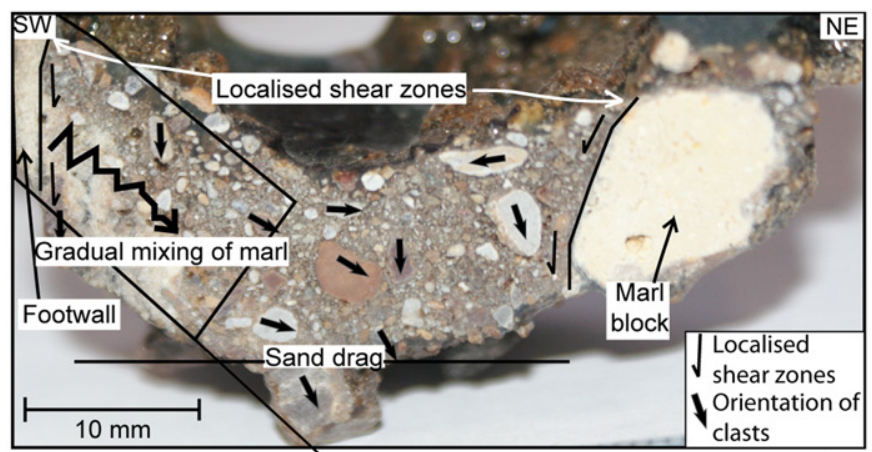

d
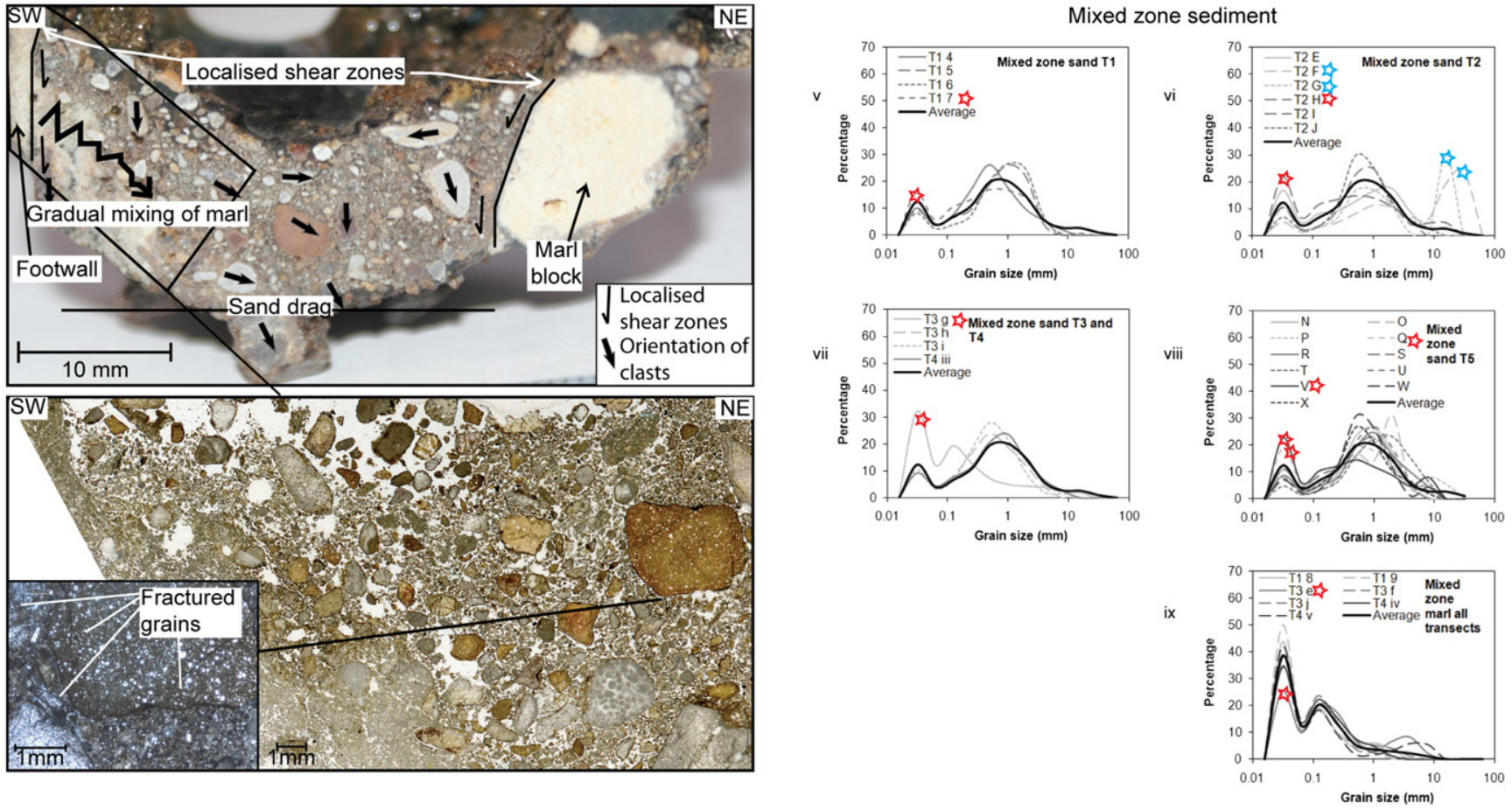

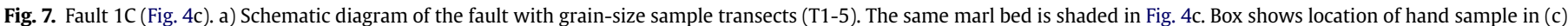

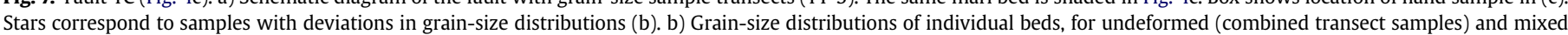

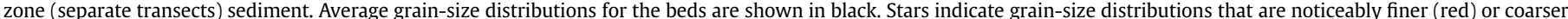

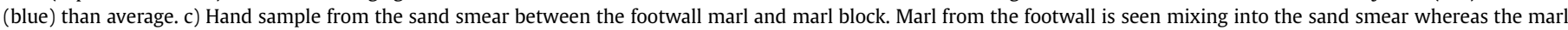

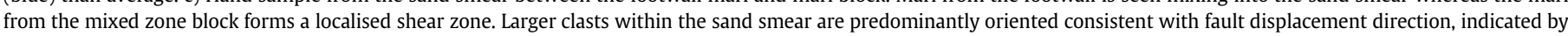

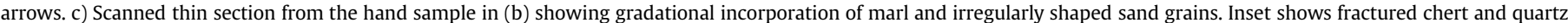
grains from this thin section. (For interpretation of the references to colour in this figure legend, the reader is referred to the web version of this article.)

(Fig. 7c). This shows a gradational footwall marl/sand contact, with the proportion of marl within the mixed zone steadily decreasing away from the contact, up to $20 \mathrm{~mm}$ into the sand smear (Fig. 7c and d). In contrast, the surface separating the cohesive marl block/sand is more discrete, with no evidence of marl mixing into the sand from this contact (Fig. 4c). This latter contact is representative of localised shear zones in the more cohesive marls indicated in Fig. 4a. The hand sample does not show modifications of the marl itself.

\subsection{Fault 5}

Fault 5 (displacement $\sim 0.6 \mathrm{~m}$ ) is probably the trace of one of the subsidiary faults in the hangingwall of Fault 1A. This fault offsets poorly lithified bedded beach gravel and alluvial sediments (Fig. 8a). The fault zone is dominated by a mixed zone in which beds are entrained and smeared, with a continuous displacement geometry. On a macro-scale there are no blocks of sediment or localised shear zones within the fault zone.

Within the gravel bed of Fault 5 there are a number of beds (labelled A to C) significantly thinner $(<0.25 \mathrm{~m})$ than the fault displacement, with visually distinctive grain-size distributions (Fig. 8a). A grain-size sample was taken from each bed from within the footwall, hangingwall, and where the bed crosses the mixed zone. Hangingwall, footwall, and mixed zone grain-size distributions of samples from these beds are plotted in Fig. 8b. These grainsize distributions show a general decrease in grain-size from the footwall to the hangingwall. All samples are classed as poorly 
sorted with little difference between the average sorting parameters for the mixed zone (1.30), hangingwall (1.33) and footwall (1.48). The standard deviation of grain-sizes is larger in the mixed zone $(0.66 \mathrm{~mm})$ than the footwall $(0.56 \mathrm{~mm})$ and hangingwall $(0.40 \mathrm{~mm})$. Small peaks exist at $1-6 \mathrm{~mm}$ within grain-size distibutions from the mixed zones of beds $A$ and $C$ (and combined samples), and are possibly also present within bed B (although this is difficult to deduce over the original sediment variability). These peaks are not found in the hangingwall or footwall samples.

A hand sample taken from the mixed zone/footwall boundary provides a more detailed view of the well defined beds 1 to 4 , both inside and outside the mixed zone (Fig. 8c). The well sorted coarse sand bed 3 can be traced throughout the footwall, and $10 \mathrm{~mm}$ into the mixed zone after which point it is mixed with surrounding beds. Individual beds can also be distinguished in footwall thin sections but not in those taken from the mixed zone (compare thin sections in Fig. 8d and e). Within this hand sample, grains, and in particular the larger clasts, are aligned in the direction of fault displacement. This pattern appears less pronounced closer to the centre of the mixed zone (Fig. 8c).

The distinct zone of fine matrix (grain-size $<0.25 \mathrm{~mm}$ ) (Fig. 8e), zone of irregularly shaped grains proximal to a larger clast (Fig. 8f), in addition to evidence of fragmented grains (Fig. $8 \mathrm{~g}$ ) seen in thin sections, suggest that there may be some grain fracturing within the mixed zone. Grain shapes are compared between footwall and mixed zone thin sections in an attempt to quantify this (Fig. $8 \mathrm{~h} \mathrm{i}$ and ii). In grains of all lithologies there is a greater proportion of equant grains and with those with ragged edges within the mixed zones, than within the footwall. However, limestone grains are more angular, whereas chert and quartz are less angular in the mixed zone than the footwall. Overall there is a higher proportion of limestone grains within the mixed zone.

\subsection{Combined data}

Average fault thicknesses for the eight faults are presented in Fig. 9. This shows a general increase in fault thickness with displacement $\left(R^{2}=0.57\right)$. There is a strong correlation between fault thickness and displacement for unlithified sediments $\left(R^{2}=0.99\right)$ although this is based on only three data points. The correlation is weaker for faults cutting heterogeneous sediment $\left(R^{2}=0.34\right)$. Error bars indicate the high variability of fault thickness within each fault zone, particularly within the heterogeneous sediment. There is no significant difference in overall fault dip between poorly lithified and heterogeneous sediment (Fig. 9).

\section{Discussion}

In corroboration of previous studies, we find fault zone architecture in poorly lithified sediment deviates from those within crystalline rocks (cf. Caine et al., 1996) or high porosity sandstones (cf. Antonellini and Aydin, 1995). All fault zones in the Loutraki study area are composed predominantly of a mixed zone, with minor damage zones often confined to individual beds. We find that fault zone structural elements vary as a function of rheology and as such we discuss the characteristic fault architecture and deformation mechanisms for faults displacing only poorly lithified sediments and those displacing sediments of contrasting competency separately.

\subsection{Deformation in poorly lithified sediment}

\subsubsection{Fault zone architecture}

The mixed zones of faults within poorly lithified, low competency sediment in the Loutraki study area are composed of entrained beds that have been rotated and subsequently smeared and attenuated along the fault trace (Figs. 4a and 8a). Sediment disaggregation within the mixed zone during fault zone deformation can destroy original sedimentary bedding (Fig. 4a). In faults where displacement exceeds the original bed thickness we sometimes find a zone of sediment apparently mixed at the grain scale (e.g. Mozley and Goodwin, 1995; Heynekamp et al., 1999) (Fig. 4a). In the damage zones, disaggregation bands appear to be confined to sediment of coarse sand size or finer (Fig. 4b), whereas subsidiary faults are found to affect all beds (Fig. 4a).

\subsubsection{Clast rotation}

Mechanical clast rotation causes an overall grain-shape preferred orientation within mixed zones (Figs. 5, 6a, b and 8c) and results from simple shear accommodation by particulate flow within poorly lithified sediment (Goodwin and Tikoff, 2002). Similar observations have been made within shear deformation bands in gravels (Exner and Grasemann, 2010), sands (Cashman and Cashman, 2000), and silts and clays (Arch and Maltman, 1990) as well as within fault cores and mixed zones (Mozley and Goodwin, 1995; Rawling and Goodwin, 2006; Balsamo et al., 2008). This grain-shape preferred orientation develops in a similar way to lineations in fault gouge and metamorphic shear zones (see Goodwin and Tikoff, 2002). Clasts in poorly lithified sediment can be considered as individual units that rotate when subjected to simple shear. Angular velocity of the clast is at a minimum when its long axis is co-incidental with the direction of shear, thus despite continued rotation the clast spends longest oriented in the direction of shear (Piazolo et al., 2002; Johnson et al., 2009). Consequently, at a single point in time, a significant proportion of clasts will be orientated in the direction of shear, thus a grain-shape preferred orientation develops. The variation of clast orientations within mixed zones is in part due to the continued clast rotation under shear deformation (Ildefonse et al., 1992a).

Closer examination of our results has shown additional characteristics of grain-shape preferred orientation within mixed zones. Larger grains exhibit a greater tendency to rotate in the direction of fault displacement than small grains or zones of groundmass, which may dip in disparate directions (Figs. 6a, b and 8c). This may be because large clasts create heterogeneous strain patterns around themselves, which have been found to affect both matrix foliation or other clasts (in matrix supported or closely packed sediments respectively) for a distance of up to twice the length of the clast, from the clast itself (Ildefonse et al., 1992a, 1992b). We also find an increase in variability of clast orientation with distance from the mixed zone margin (Figs. 5c and 8c), that probably results from a greater number of clast interactions with increased bulk strain (Ildefonse et al., 1992a).

\subsubsection{Grain scale mixing}

Mixing of grains from different sediment is another characteristic of particulate flow in poorly lithified sediment. We observe grain-scale mixing occurring within the mixed zones in coarse sand/pebbles (Fig. 8c) and between silty marl and sand (Fig. 7c and $\mathrm{d}$ ). Yet sampled grain-size distributions do not appear to be greatly influenced by mixing processes in Fault 5 . Whilst the increased standard deviation for each sampled bed in the mixed zone of Fault 5, compared to the footwall and hangingwall (Fig. 8b), may result from grain-scale mixing with surrounding beds, there is no corresponding decrease in sediment sorting. Therefore, it appears that within Fault 5 natural sediment variability dominates over grain-scale mixing processes, a situation that may also hold true for other mixed zones in small displacement $(<1 \mathrm{~m})$ faults. Conversely, an increase in the fine fraction $(<0.03 \mathrm{~mm})$ of between $5 \%(\mathrm{~g})$ and $20 \%(\mathrm{~V})$, is detectable in grain- 
a

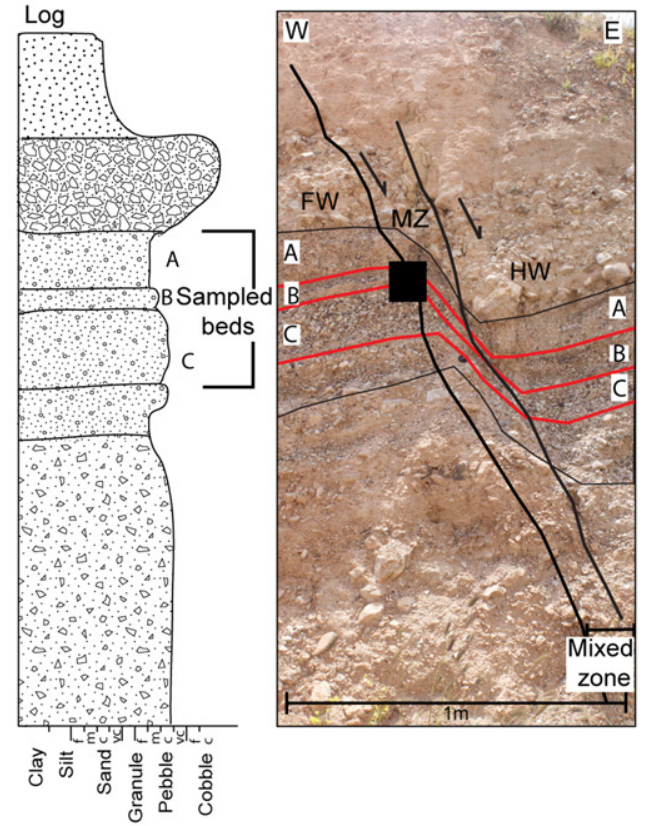

b
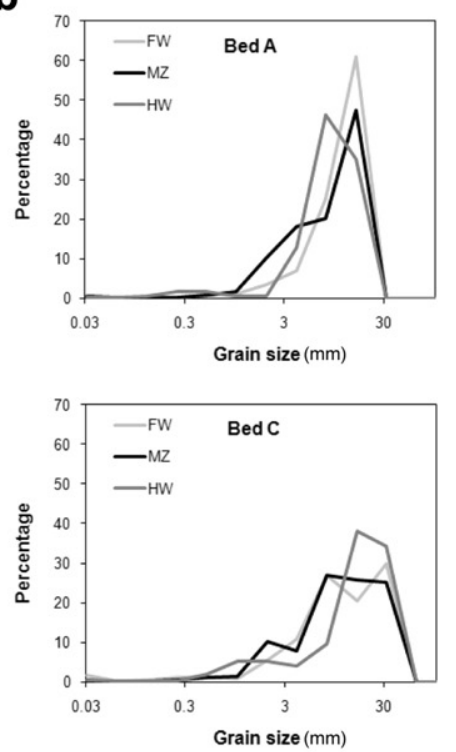
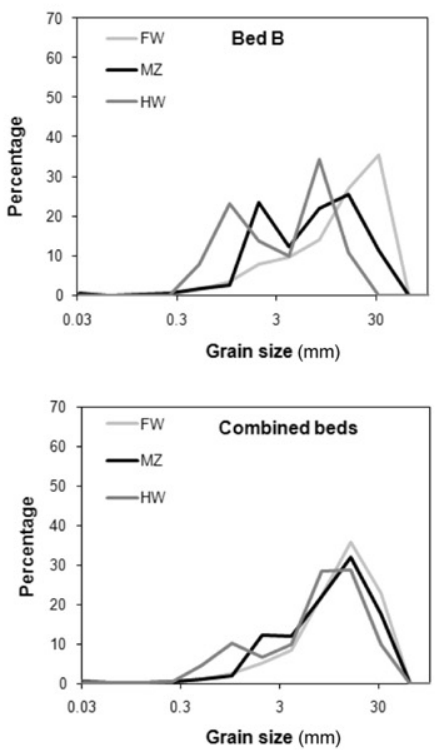

C

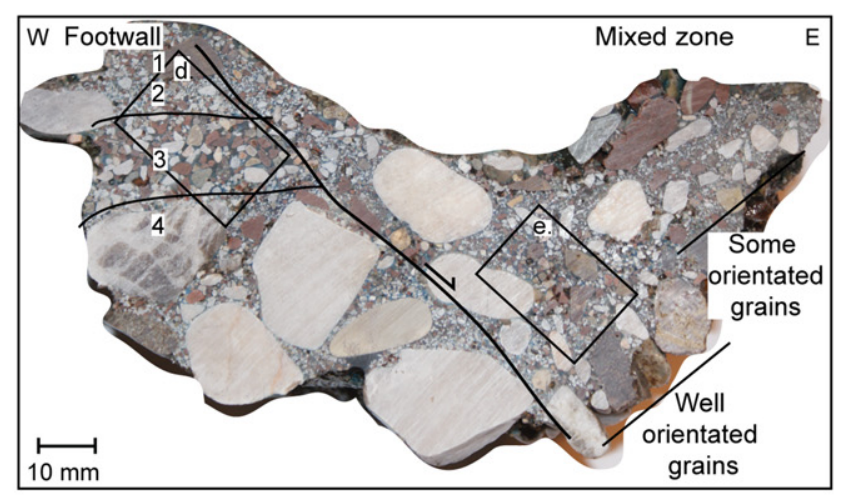

d

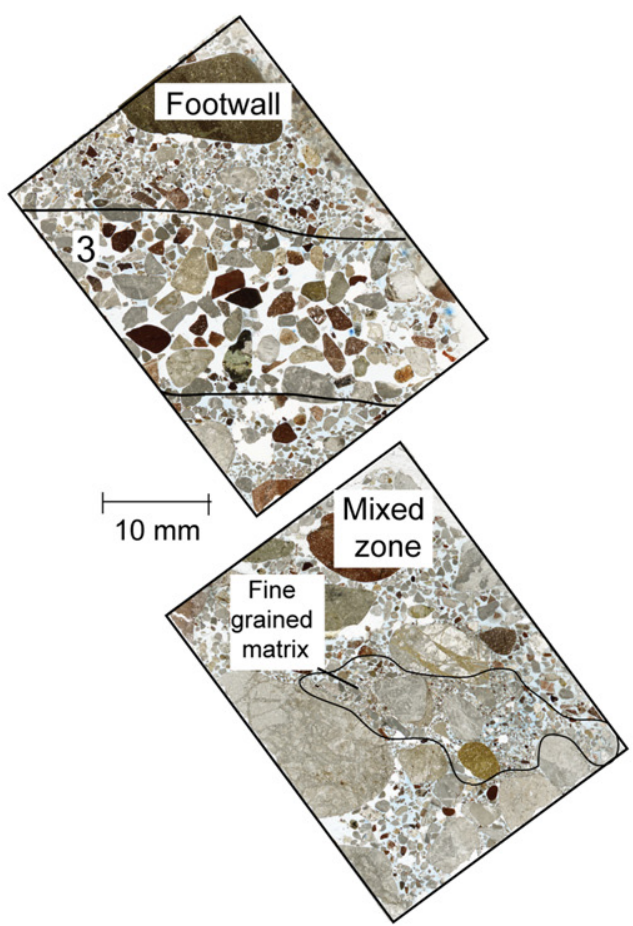

f

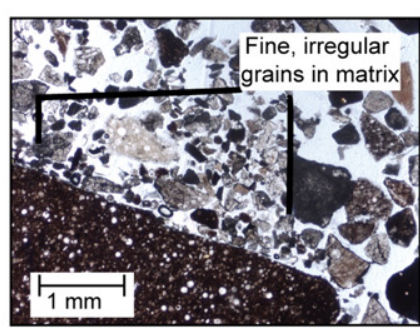

g

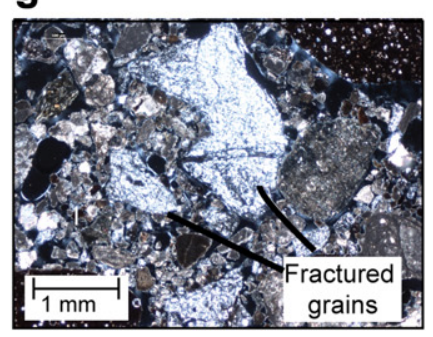

h

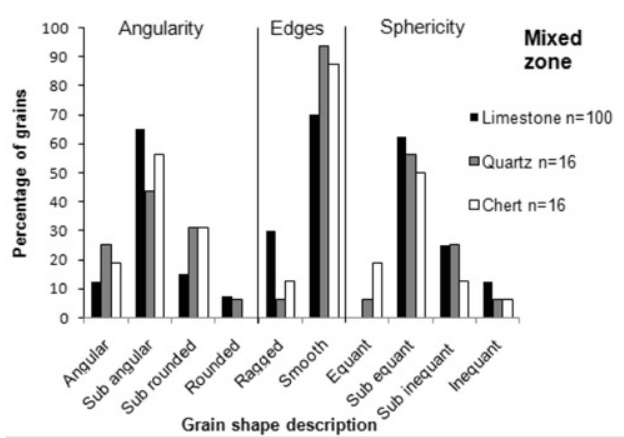

ii

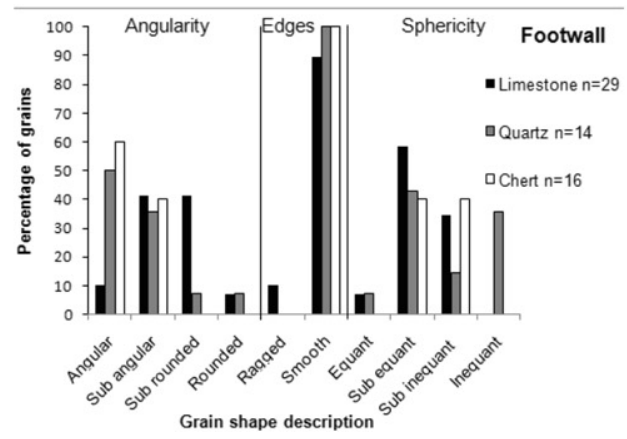


size distributions for four sand samples from the mixed zone of Fault 1C (Fig. 8). These samples were all sourced from sand proximal to contacts with marl beds $(<50 \mathrm{~mm})$ indicating that these peaks may result from marl grains mixing into the sand bed, which can be seen occurring in Fig. 7c and d. It is likely that mixing is more easily detected in these samples because the sediments have less variability. The degree of grain-scale mixing appears to increase with fault displacement and bulk strain, however, as demonstrated by the presence of a zone of mixed sediment in Fault 1A compared to Fault 5 (Figs. 4a and 8a).

\subsubsection{Cataclasis}

Grain-size distibutions of a small number of mixed zone samples deviate slightly from the sample averages in Faults $1 \mathrm{C}$ (Fig. 7b) and source beds of Fault 5 (Fig. 8b). Grain-size distributions of three samples from Fault $1 \mathrm{C}(8, \mathrm{~V}$ and $\mathrm{H}$ in Fig. $7 \mathrm{~b})$ exhibit a broader modal peak than the average. In grain-size samples from Fault 5 there is a slight increase in the proportion of sediment at 2-6 $\mathrm{mm}$ in grain-size distributions from the mixed zone samples of beds $A$ and $C$ of (Fig. $8 \mathrm{~b}$ ). In both faults these variations may be caused by an increase in proportion of fine-grained sediment that may result from mixed zone deformation processes. An increase in finer sediment fractions has previously been observed from the fault cores (Balsamo et al., 2008; Balsamo and Storti, 2011) and cataclastic deformation bands (Cashman and Cashman, 2000; Rawling and Goodwin, 2003) of fault zones in poorly lithified sediment, and attributed to the process of cataclasis (e.g. Sammis et al., 1987).

The overall increase of both the equancy and angularity of grains within the mixed zone compared to the footwall was also observed by Balsamo and Storti (2011), and attributed to the chipping of grains as they roll due to particulate flow. The increase in proportion of rounded chert and quartz grains within the mixed zone may be because of their initial irregularity such that chipping actually removes asperities. However differences may also stem from a difference in fracturing mechanisms resulting from contrasting grain hardness (Rawling and Goodwin, 2003), whereby grains composed of harder minerals (in this case quartz and chert) fracture by spalling or flaking, in contrast to softer lithic grains (limestone) (Middleton and Wilcock, 1999) that can fracture intra-granularly. The higher proportion of limestone fragments may result from pervasive intra-granular fracturing of limestone grains producing a greater number of daughter fragments than were a grain to singularly flake or spall under equivalent stress. Furthermore, the greater proportion of limestone grains with ragged edges within the mixed zone in comparison to quartz and chert may reflect the relative weakness of these grains. The grain-shape disparities between footwall and the mixed zone sediments of Fault 5 (Fig. 8h), and evidence of fractured grains within thin sections (Figs. 6e, $\mathrm{f}$ and $8 \mathrm{~g}$ ) supports the supposition that cataclasis has occurred within these mixed zones.

The limited evidence of cataclasis indicates that it is unlikely to be the dominant deformation mechanism within these mixed zones. Instead it is more likely to arise as a secondary effect of controlled particulate flow whereby continued particulate flow and deformation within the mixed zone is facilitated by the fracturing

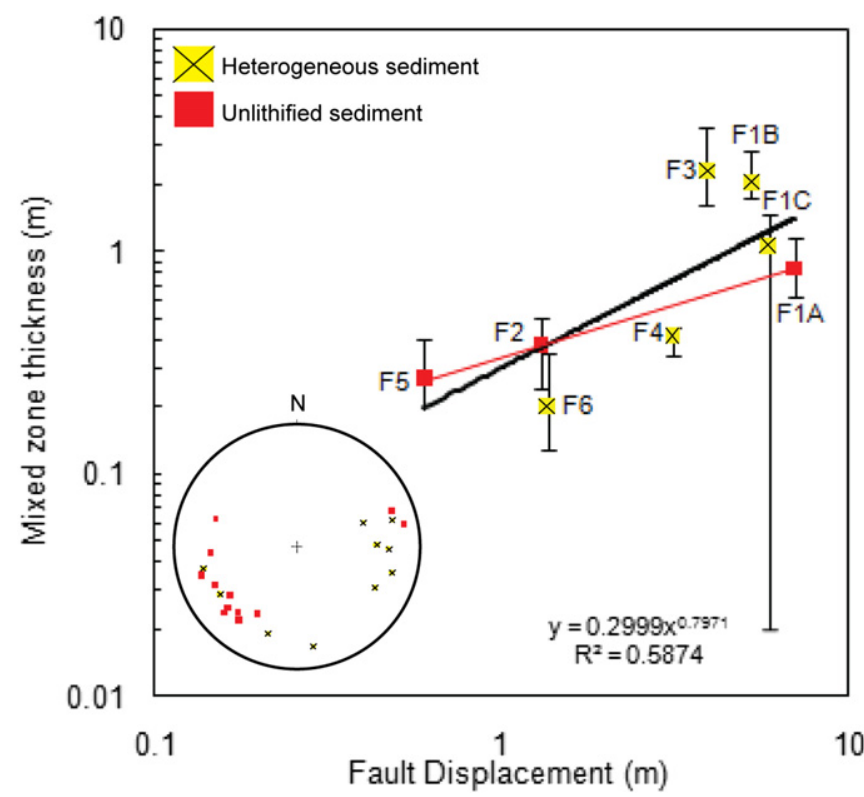

Fig. 9. Fault thickness and displacement for eight faults in the Loutraki section, in unlithified, and heterogeneous (due to cemented beds or cohesive marl) sediment. Minimum and maximum thicknesses are indicated by error bars. The black trendline and equations relate to all of the faults. Red line is the trendline for poorly lithified sediment only. Stereonet inset shows poles to planes for apparent fault dip orientations for poorly lithified sediment (red squares) and heterogeneous sediment (yellow circles). (For interpretation of the references to colour in this figure legend, the reader is referred to the web version of this article.)

of occasional grains (Borradaile, 1981). This would be consistent with earlier outcrop studies of deformation mechanisms in deformation bands and fault cores in poorly lithified sediment (Rawling and Goodwin, 2003; Balsamo et al., 2008). Nethertheless the presence of cataclasis within these fault zones, while minor, supports previous suggestions that high confining pressures are not required for cataclasis to occur (cf. Cashman and Cashman, 2000; Rawling and Goodwin, 2003; Balsamo and Storti, 2011).

\subsubsection{Fault growth}

The overall positive correlation between fault displacement and fault thickness that we find in the Loutraki fault array (Fig. 9) is a pattern common to faults cutting all lithologies (e.g. Childs et al., 1996a, 2009; Shipton et al., 2006). The apparent linear increase in fault thickness with displacement in faults within poorly lithified sediment (Fig. 9) may result from a continuous contribution of adjacent sediment, possibly via particulate flow (Rawling and Goodwin, 2003; Caine and Minor, 2009). Fig. 10b is a model based on our results, of a progressively widening mixed zone in poorly lithified sediment, due to the incorporation of new material and strain accommodation via particulate flow. Deformation is initially manifested in the rotation of grains and disaggregation of sediment, which progresses to the smearing of beds and grain-scale mixing with increasing fault displacement, during which time incipient cataclasis may also occur.

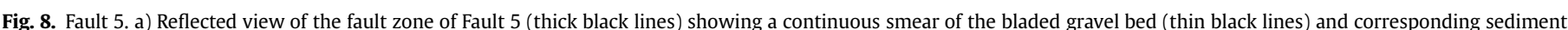

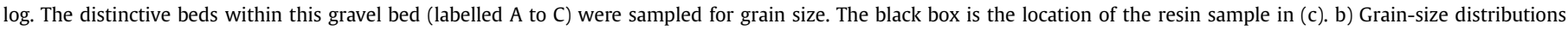

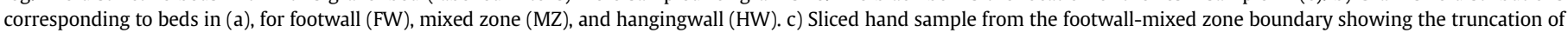

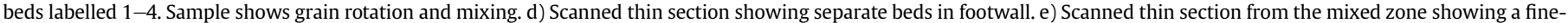

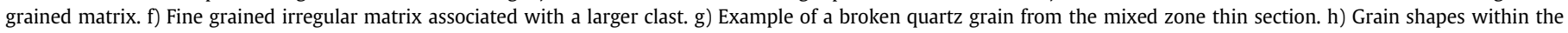
mixed zone (i) and footwall (ii) from thin sections. 


\subsection{Deformation in sediment of contrasting competency}

\subsubsection{Fault zone architecture}

Mixed zones of faults displacing sediment of contrasting competency are more complex than those within poorly lithified sediment at the Loutraki outcrop. The most important difference is the existence of localised shear zones. Localised shear zones occur in marls and coarser sediments that are mechanically stronger than un-cemented sands and gravels due to the presence of silt and clay (Middleton and Wilcock, 1999) or cement (Arch and Maltman, 1990) (Fig. 4). In poorly lithified beds, deformation is still distributed across the mixed zone. The dip of fault zone contacts are on average $10^{\circ}$ to $20^{\circ}$ steeper where strain is localised than where strain is distributed across the mixed zone (Fig. $4 \mathrm{~b}$ and c), although overall fault dip does not differ from faults in poorly lithified sediment (Fig. 9) (Rawling and Goodwin, 2006). Localised shear zones may bound blocks or lenses of cohesive sediment within the mixed zone that have largely intact bed characteristics (Fig. 4c), as described in earlier outcrop studies (Heynekamp et al., 1999; Rawling and Goodwin, 2006; Minor and Hudson, 2006; Kristensen et al., 2008; Wilson et al., 2009).
Localised shear zones may influence fault architecture without creating lenses or blocks. The mixed zone of Fault $1 \mathrm{~B}$ is dominated by smeared beds, similar to Fault $1 \mathrm{~A}$, yet they are less internally deformed (compare Fig. 4a and b). We hypothesise that this may be either due to deformation localisation along the shear zone at the cemented footwall/mixed zone boundary, rather than by significant disaggregation and bed mixing such as within Fault 1A, or, because Fault $1 \mathrm{~B}$ is wider than Fault $1 \mathrm{~A}$ ( $2 \mathrm{~m}$ and $0.8 \mathrm{~m}$ respectively), the intensity of grain-scale deformation may be reduced as strain is distributed over a wider area. The increased width of Fault 1B is probably due to the footwall/mixed zone boundary stepping back into the footwall resulting from a change strain distribution and contact dip where the sediment competency changes above bed $\mathrm{E}$.

\subsubsection{Fault growth}

The weaker correlation between fault displacement and fault thickness in faults cutting beds of heterogeneous rheology, compared to those in poorly lithified sediment $\left(R^{2}=0.34\right.$ and 0.99 respectively) suggests that a mechanism other than particulate flow may govern evolution of these faults. The intermittent fault thickness increase with fault displacement that we see here may be

a

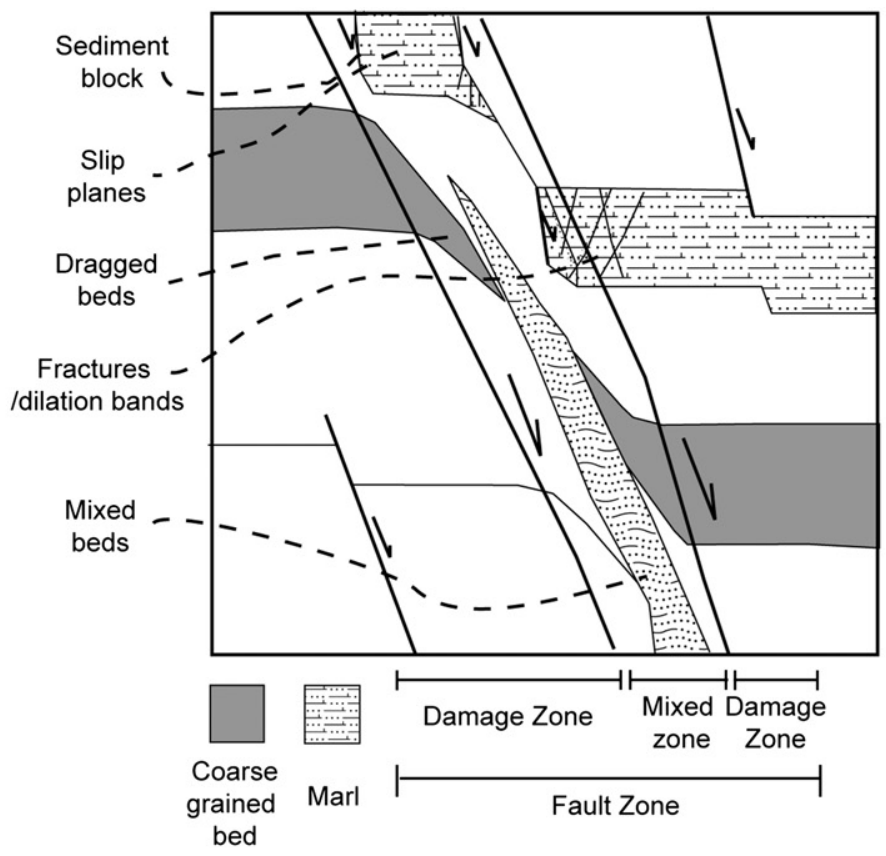

b

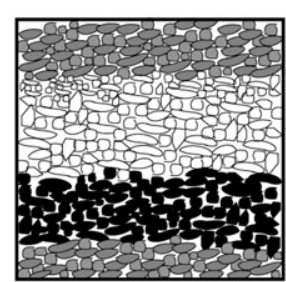

Undisturbed sediment

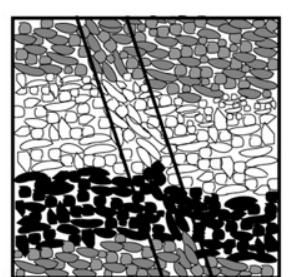

Sediment disaggregation, bed and grain rotation

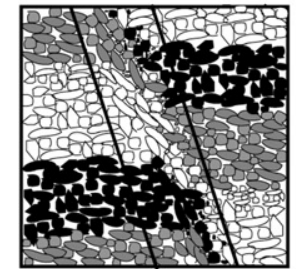

Sediment mixing and incipient cataclasis
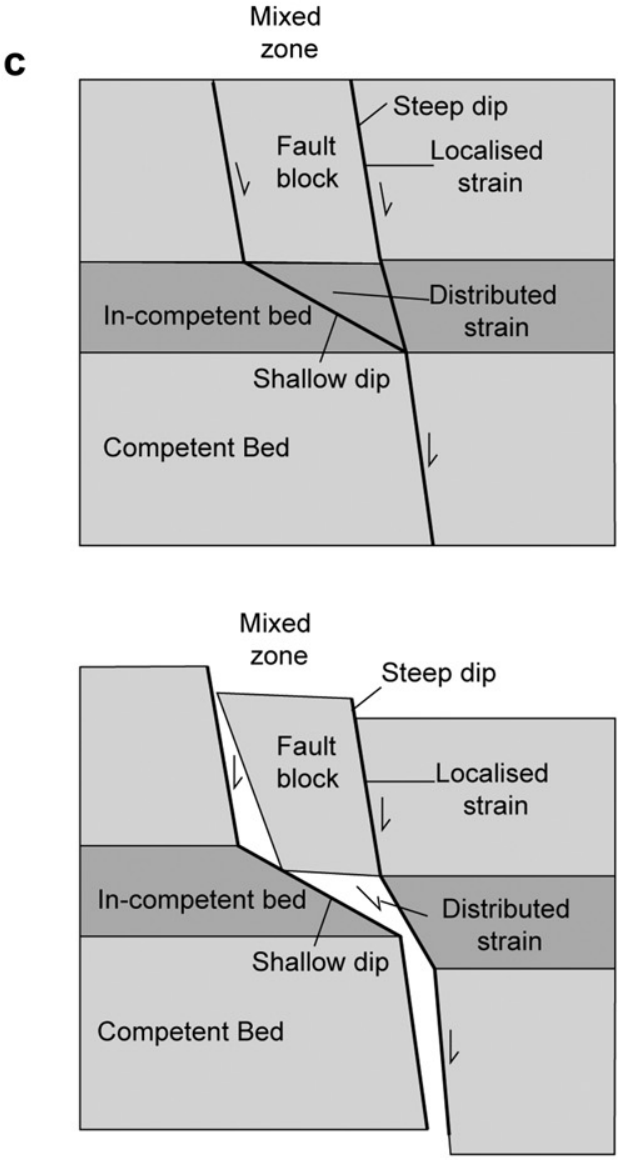

Increasing displacement

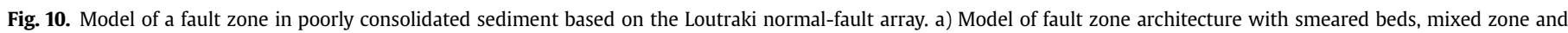

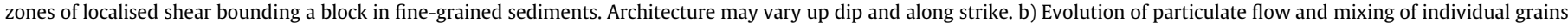

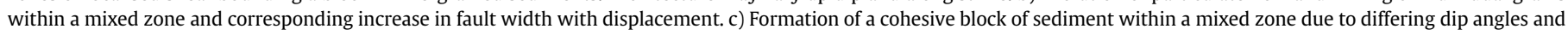
localisation of strain in beds of different rheologies, similar to Childs et al. (1996a). 
associated with the occurrence of blocks and lenses within the fault zone, and result from fault-tip bifurcation (Watterson et al., 1998; Rawling and Goodwin, 2006; Childs et al., 2009). Deflection of a fault trace may occur due to contrasting bed competencies (Antonellini and Aydin, 1995; Childs et al., 1996b, 2009; Rawling and Goodwin, 2006; Bastesen et al., 2009) or bed friction angles (Egholm et al., 2008). This creates asperities at the mixed zone boundary that are removed with subsequent fault displacement, incorporating whole blocks of sediment within the mixed zone (Rawling and Goodwin, 2006). Fault-tip bifurcation may also occur along strike (Childs et al., 1996b). Fig. 10c shows the evolution of a block of sediment within a mixed zone based on Fault 1C, due to alternating strain localisation and distribution.

It has also been suggested that fault tip-line bifurcation may produce smears within faults (e.g. Egholm et al., 2008). Where a fault segment steps into the footwall (Childs et al., 1996a), slip along near-vertical, localised shear zones causes an increase in pressure in the shallow dipping, weaker beds that connect the steeply dipping fault segments. This pressure forces sediment into a region of lower pressure - the fault zone. This process may contribute to the supply of sand to the mixed zone at the back-step of Fault 1B.

\subsection{Implications}

The majority of previous studies of fault zones in poorly lithified sediment report mixed zones, fault cores and damage zones (Heynekamp et al., 1999; Rawling et al., 2001; Caine and Minor, 2009), but fault zones consisting of only a fault core are also found to occur (Balsamo and Storti, 2010). The mixed zone dominated faults described here contribute to the range of potential fault architectures in poorly lithified sediment. Fig. 10a illustrates this architecture and shows that mixed zones within the same fault may be dominated by smeared beds or sedimentary blocks at different points in time and space.

In contrast to previous work we have not observed fault cores in any fault zones (Mozley and Goodwin, 1995; Heynekamp et al., 1999; Sigda et al., 1999; Rawling et al., 2001). The absence of low permeability clay fault cores or shear deformation bands is potentially of hydrological significance, since both would be likely barriers to cross-fault fluid flow (Rawling et al., 2001; Caine and Minor, 2009). However, heterogeneities within sediments resulting from mixed zones also have the potential to impact fluid flow, potentially behaving as barriers to cross-fault fluid flow (Caine and Minor, 2009) or as conduits, with fluid-flow focused along smears (Bense and Van Balen, 2003). As mixed zones evolve, their hydrological effects are likely to increase as a result of continued particulate flow (Fig. 10b) and the incorporation of additional blocks of sediment (Fig. 10c). Importantly, mixed zones in poorly lithified sediment or sediment of heterogeneous rheology may have different impacts on fluid flow.

\section{Conclusion}

We find mixed zones to be the principal architectural element of the fault zones in poorly lithified sediment in this study. Variations in the structural characteristics of these mixed zones result from sediment rheology, stratigraphy and fault displacement.

In fault zones within poorly lithified sediments, strain is distributed across the mixed zone within rotated and smeared beds. Based on microstructural observations we infer that mixed zone deformation occurs via particulate flow resulting in considerable grain rotation and grain-scale mixing of smeared beds. The presence of broken grains, grain shape and grain-size distribution changes suggest that an element of cataclasis facilitates particulate flow. Increasing fault displacement can result in zones of mixed sediment within the mixed zones.

The greater competency of marls and locally cemented sediments within the study area enables deformation along localised shear zones. Fault tip-bifurcation occurs as a consequence of vertically contrasting rheologies and creates asperities along the mixed zone boundary and the removal of which can result in the formation cohesive lenses and blocks of sediment within the mixed zone.

These findings suggest that even faults with minor displacements may impact subsurface fluid flow, although the impact is likely to be greater with increased fault displacement due to the increase in sediment deformation. The prominence of mixed zones over impermeable fault cores and damage zones in these fault zones in poorly lithified sediment indicates that the range of impacts of fault zones on subsurface fluid flows may be greater than previously considered.

\section{Acknowledgements}

We are sincerely grateful for thorough and constructive reviews from Dr. Ulrike Exner and an anonymous reviewer whose comments have significantly improved the quality of the manuscript. This work was funded as part of a UK Natural Environment Research Council PhD project NE/G524095/1. We thank the Greek Institute of Geology and Mineral Exploration for allowing us to carry out field work in this area and Mike Loveless and Stuart Vinen for their assistance in the field.

\section{References}

Antonellini, M., Aydin, A., 1994. Effect of faulting on fluid flow in porous sandstones: Petrophysical properties 1. AAPG Bulletin 78 (3), 355-377.

Antonellini, M., Aydin, A., 1995. Effect of faulting on fluid flow in porous sandstones: geometry and spatial distribution. AAPG Bulletin 79 (5), 642-671.

Arch, J., Maltman, A., 1990. Anisotropic pemeability and tortuosity in deformed wet sediments. Journal of Geophysical Research 95 (B6), 9035-9045.

Aydin, A., 1978. Small faults formed as deformation bands in sandstone. Pure and Applied Geophysics 116, 913-930.

Balsamo, F., Storti, F., Piovano, B., Salvini, F., Cifelli, F., Lima, C., 2008. Time dependent structural architecture of subsidary fracturing and stress pattern in the tip region of an extensional growth fault system, Tarquinia basin, Italy. Tectonophysics $454,54-69$.

Balsamo, F., Storti, F., 2010. Grain size and permeability evolution of soft-sediment extensional sub-seismic and seismic fault zones in high-porosity sediments from the Crotone basin, Southern Appenines, Italy. Marine and Petroleum Geology 27, 822-837.

Balsamo, F., Storti, F., 2011. Size-dependent comminution, tectonic mixing, and sealing behavior of a "structurally oversimplified" fault zone in poorly lithified sands: evidence for a coseismic rupture? Geological Society of America Bulletin 123, 613-619.

Bastesen, E., Braathen, A., Nøttveit, H., Gabrielsen, R.H., Skar, T, 2009. Extensional fault cores in micritic carbonate - Case studies from the Gulf of Corinth, Greece. Journal of Structural Geology 31, 403-420.

Bense, V.F., Van Balen, R.T., 2003. Hydrogeological aspects of fault zones on various scales in the Roer Valley Rift System. Journal of Geochemical Exploration 78-79, 317-320.

Bense, V.F., Van den Berg, E.H., Van Balen, R.T., 2003. Deformation mechanisms and hydraulic properties of fault zones in unconsolidated sediments; the Roer Valley rift system, the Netherlands. Hydrogeology Journal 11, 319-332.

Bense, V.F., Van Balen, R.T., 2004. The effect of fault relay and clay smearing on groundwater flow patterns in the Lower Rhine Embayment. Basin Research 16 (3), 397-411.

Bense, V.F., Person, M.A., 2006. Faults as conduit-barrier systems to fluid flow in siliciclastic sedimentary aquifers. Water Resources Research 42, W05421.

Bense, V.F., Person, M.A., Chaudhary, K., You, Y., Cremer, N., Simon, S., 2008. Thermal anomalies indicate preferential flow along faults in unconsolidated sedimentary aquifers. Geophysical Research Letters 35, L24406.

Bornovas, J., Lalechos, N., Filippakis, N., 1972. Geological Map of Greece, Korinthos Sheet, vol. 1. IGME, Athens, p. 50000.

Borradaile, G.J., 1981. Particulate flow of rock and the formation of cleavage. Tectonophysics 72, 305-321.

Bredehoeft, J.D., Belitz, K., Sharp-Hansen, S., 1992. The hydrodynamics of the Big Horn Basin: a study of the role of faults. AAPG Bulletin 76 (4), 530-546.

Bredehoeft, J.D., 1997. Fault permeability near Yucca Mountain. Water Resources Research 33 (11), 2459-2463. 
Caine, J.S., Evans, J.P., Forster, C.B., 1996. Fault zone architecture and permeability structure. Geology 24 (11), 1025-1028.

Caine, J.S., Minor, S.A., 2009. Structural and geochemical characteristics of faulted sediments and inferences on the role of water in deformation, Rio Grande Rift, New Mexico. GSA Bulletin 121 (9-10), 1325-1340.

Cashman, S., Cashman, K., 2000. Cataclasis and deformation-band formation in unconsolidated marine terrace sand, Humboldt County, California. Geology 28, $111-114$.

Chadwick, R.A., Noy, D.J., Holloway, S., 2009. Flow processes and pressure evolution in aquifers during the injection of supercritical $\mathrm{CO} 2$ as a greenhouse gas mitigation measure. Petroleum Geoscience 15 (1), 59-73.

Childs, C., Nicol, A., Walsh, J.J., Watterson, J., 1996a. Growth of vertically segmented normal faults. Journal of Structural Geology 18 (12), 1389-1397.

Childs, C., Watterson, J., Walsh, J.J., 1996b. A model for the structure and development of fault zones. Journal of the Geological Society of London 153 337-340.

Childs, C., Manzocchi, T., Walsh, J.J., Bonson, C.G., Nicol, A., Schöpfer, M.P., 2009. A geometric model of fault zone and fault rock thickness variations. Journal of Structural Geology 31 (2), 117-127.

Collier, R.E., 1990. Eustatic and tectonic controls upon Quaternary coastal sedimentation in the Corinth basin, Greece. Journal of the Geological Society 147 (2), 301-314.

Dia, A.N., Cohen, A.S., O'Nions, R.K., Jackson, J.A., 1997. Rates of uplift investigated through ${ }^{230 T h}$ dating in the Gulf of Corinth (Greece). Chemical Geology 138, $171-184$.

Du Bernard, X., Eichbuhl, P., Aydin, A., 2002. Dilation bands: a new form of localized failure in granular media. Geophysical Research Letters 29 (4), 2176.

Egholm, D.L., Clausen, O.R., Sandiford, M., Kristensen, M.B., Korstgård, J.A., 2008. The mechanics of clay smearing along faults. Geology 36 (10), 787-790.

Exner, U., Grasemann, B., 2010. Deformation bands in gravels: displacement gradients and heterogeneous strain. Journal of the Geological Society, London 167, 905-913.

Fossen, H., Schultz, R.A., Shipton, Z.K., Mair, K., 2007. Deformation bands in sandstone: a review. Journal of the Geological Society 164, 755-769.

Goodwin, L.B., Tikoff, B., 2002. Competency contrast, kinematics, and the development of foliations and lineations in the crust. Journal of Structural Geology $24,1065-1085$.

Grauch, V.J., Hudson, M.R., Minor, S.A., 2001. Aeromagnetic expression of faults that offset basin fill, Albuquerque basin, New Mexico. Geophysics 66 (3), 707-720.

Haneberg, W.C., 1995. Steady-state groundwater-flow across idealized faults. Water Resources Research 31 (7), 1815-1820.

Heffner, J., Fairley, J., 2006. Using surface characteristics to infer the permeability structure of an active fault zone. Sedimentary Geology 184 (3-4), 255-265.

Heynekamp, M.R., Goodwin, L.B., Mozley, P.S., Haneberg, W.C., 1999. Controls on fault-zone architecture in poorly lithified sediments, Rio Grande Rift, New Mexico: Implications for fault zone permeability and fluid flow. In: Haneberg, P.S., Mozley, P.S., Moore, J.C., Goodwin, L.B. (Eds.), Faults and Subsurface Fluid Flow in the Shallow Crust, vol. 113. American Geophysical Union Monograph, pp. 27-49.

Holcombe, R.J., 2010. GEOrient V9.4.2. Structural Geology - Mapping/GIS Software. University of Queensland, Aurstralia. http://www.holcombe.net.au/software/ rodh_software_georient.htm [accessed 20/08/2010].

Ildefonse, B., Launeau, P., Bouchez, J.-L., Fernandez, A., 1992a. Effect of mechanical interactions on the developments of shape preferred interactions: a twodimensional experimental approach. Journal of Structural Geology 14 (1), $73-83$.

Ildefonse, B., Sokoutis, D., Mancktelow, N.S., 1992b. Mechanical interactions between rigid particles in a deforming ductile matrix. Analogue experiments in simple shear flow. Journal of Structural Geology 14 (10), 1253-1266.

Johnson, S.E., Lenferink, H.J., Price, N.A., Marsh, J.H., Koons, P.O., West Jr., D.P., Beane, R., 2009. Clast-based kinematic vorticity gauges: the effects of slip at matrix/clast interfaces. Journal of Structural Geology 31, 1322-1339.

Kristensen, M.B., Childs, C.J., Korstgard, J.A., 2008. 3D geometry of small-scale relay zones between normal faults in soft sediments. Journal of Structural Geology 30, 257-272.

Leeder, M.R., Portman, C., Andrews, J.E., Collier, R.E., Finch, E., Gawthorpe, R.L., 2005. Normal faulting and crustal deformation, Alkonides Gulf and Perachora Peninsula, eastern Gulf of Corinth rift, Greece. Journal of the Geological Society $162,549-561$.
Lindsay, N.G., Murphy, F.C., Walsh, J.J., Watterson, J., 1993. Outcrop studies of shale smears on fault surfaces. In: Fint, S.S., Bryant, I.D. (Eds.), The Geological Modelling of Hydrocarbon Reservoirs and Outcrop Analogues, vol. 15. Blackwell Scientific Publications, Oxford, pp. 11-123.

Mailloux, B.J., Person, M., Kelley, S., Dunbar, N., Cather, S., Strayer, L., Hundleston, P. 1999. Tectonic controls on the hydrogeology of the Rio Grande rift, New Mexico. Water Resources Research 35, 2641-2659.

Middleton, G.V., Wilcock, P.R., 1999. Mechanics in the Earth and Environmenta Sciences. Cambridge University Press, Cambridge.

Minor, S.A., Hudson, M.R., 2006. Regional Survey of structural properties and cementation patterns of fault zones in the Northern part of the Albuquerque basin, New Mexico - Implications for Ground-water Flow U.S. Geological Survey Professional Paper 1719.

Mozley, P.S., Goodwin, L.B., 1995. Patterns of cementation along a Cenozoic normal fault: a record of paleoflow orientations. Geology 23 (6), 539-542.

Perry, C., Taylor, K., 2007. Environmental Sedimentology. Blackwell Publishing, Oxford.

Person, M., Goodwin, L.B., Rawling, G., Connell, S., 2000. The evolution of fault-zone permeabiility and groundwater flow patterns within the Albuquerque Basin of the Rio Grande Rift, NM. Journal of Geochemical Exploration 69-70, 565-568.

Piazolo, S., Bons, P.D., Passchier, C.W., 2002. The influence of matrix rheology and vorticity on fabric development of populations of rigid objects during plane strain deformation. Tectonophysics 351, 315-329.

Rawling, G.C., Goodwin, L.B., Wilson, J.L., 2001. Internal architecture, permeability structure, and hydrologic significance of contrasting fault-zone types. Geology 29 (1), 43-46.

Rawling, G.C., Goodwin, L.B., 2003. Cataclasis and particulate flow in faulted, poorly consolidated sediments. Journal of Structural Geology 25, 317-331.

Rawling, G.C., Goodwin, L.B., 2006. Structural record of the mechanical evolution of mixed zones in poorly lithified sediments, Rio Grande rift, New Mexico, USA. Journal of Structural Geology 28 (9), 1623-1639.

Rey, D., Rubio, B., Bernabeu, A.M., Vilas, F., 2004. Formation, exposure, and evolution of a high-latitude beachrock in the intertidal zone of the Corrubedo complex (Ria de Arousa, Galicia, NW Spain). Sedimentary Geology 169, 93-105.

Roberts, G.P., Haughton, S.L., Underwood, C., Papanikolaou, I., Cowie, P.A., van Calsteren, P., Wigley, T., Cooper, F.J., McArthur, J.M., 2009. Localization of Quaternary slip rates in an active rift in $10^{5}$ years: An example from central Greece constrained by ${ }^{234}$-U- ${ }^{230 T h}$ coral dates from uplifted paleoshorelines. Journal of Geophysical Research 114, B10406.

Sammis, C., King, G., Biegel, R., 1987. The kinematics of gouge deformation. Pure and Applied Geophysics 125 (5), 777-812.

Shipton, Z.K., Evans, J.P., Robeson, K.R., Forster, C.B., Snelgrove, S., 2002. Structura heterogeneity and permeability in faulted eolian sandstone: Implications for subsurface modeling of faults. AAPG Bulletin 86 (5), 863-883.

Shipton, Z.K., Soden, A.M., Kirkpatrick, J.D., Bright, A.M., Lunn, R.J., 2006. How thick is a fault? Fault displacement-thickness scaling revisited. In: Abercrombie, R. (Ed.), Earthquakes: Radiated Energy and the Physics of Faulting. American Geophysical Union, pp. 193-198.

Sibson, R.H., 1977. Fault rocks and fault mechanisms. Journal of the Geological Society $133,191-213$

Sigda, J.M., Goodwin, L.B., Mozley, P.S., Wilson, J.L., 1999. Permeability alteration in small-displacement faults in poorly lithified sediments: Rio Grande Rift, Central New Mexico. In: Haneberg, P.S., Mozley, P.S., Moore, J.C., Goodwin, L.B. (Eds.), Faults and Subsurface Fluid Flow in the Shallow Crust, vol. 113. American Geophysical Union Monograph, Washington, D.C, pp. 51-68.

Stamatis, G., Voudouris, K., 2003. Marine and human activity influences on groundwater quality of Southern Korinthos area (Greece). Hydrological Processes 17, 2327-2345.

Sternlof, K.R., Karimi-Fard, M., Pollard, D.D., Durlofsky, L.J., 2006. Flow and transport effects of compaction bands in sandstone at scales relevant to aquifer and reservoir management. Water Resources Research 42 (7), W07425.

Turner, J.A., Leeder, M.R., Andrews, J.E., Rowe, P.J., Van Calsteren, P., Thomas, L., 2010. Testing rival tectonic uplift models for the Lechaion Gulf in the Gulf of Corinth rift. Journal of the Geological Society 167, 1237-1250.

Watterson, J., Childs, C., Walsh, J.J., 1998. Widening of fault zones by erosion of asperities formed by bed-parallel slip. Geology 26, 71-74.

Wilson, P., Gawthorpe, R.L., Hodgetts, D., Rarity, F., Sharp, I.R., 2009. Geometry and architecture of faults in a syn-rift normal fault array: the Nukhul half-graben, Suez rift, Egypt. Journal of Structural Geology 31 (8), 759-775. 